\title{
Avaliação de Desempenho em Uso e Manutenção de Habitações em Sistemas Construtivos Inovadores
}

\author{
Rosaria Ono \\ Mena Cristina Marcolino Mendes \\ Márcio Minto Fabricio \\ Sheila Walbe Ornstein \\ Fabiana Lopes de Oliveira \\ Lucas Melchiori Pereira
}

\section{Introdução}

Este capítulo aborda a aplicação de instrumentos de verificação e avaliação de desempenho da operação, uso e manutenção em campo, desenvolvidos como parte da metodologia para avaliação de sistemas construtivos inovadores, previamente apresentados nos capítulos três (http://dx.doi.org/10.4322/978-85-89478-42-7-04) e seis (http://dx.doi. org/10.4322/978-85-89478-42-7-07) do primeiro volume desta coletânea (FABRICIO; ONO, 2015). A aplicação foi realizada por equipe técnica constituída por três duplas de profissionais de engenharia civil e arquitetura, em um empreendimento habitacional de interesse social de unidades familiares isoladas.

Essa atividade em campo teve como objetivo principal aperfeiçoar e validar tais instrumentos (Figura 1), que compóem parte de um conjunto de instrumentos de avaliação de desempenho para homologação de tecnologias inovadoras, proposto ao SiNAT (Sistema Nacional de Avaliação Técnica de Sistemas Inovadores e Convencionais) do Ministério das Cidades. 
Adicionalmente, a atividade ofereceu a oportunidade de analisar e discutir o desempenho das unidades habitacionais inspecionadas com a aplicação integrada dos instrumentos de aplicação em campo (in loco) no estudo de caso.

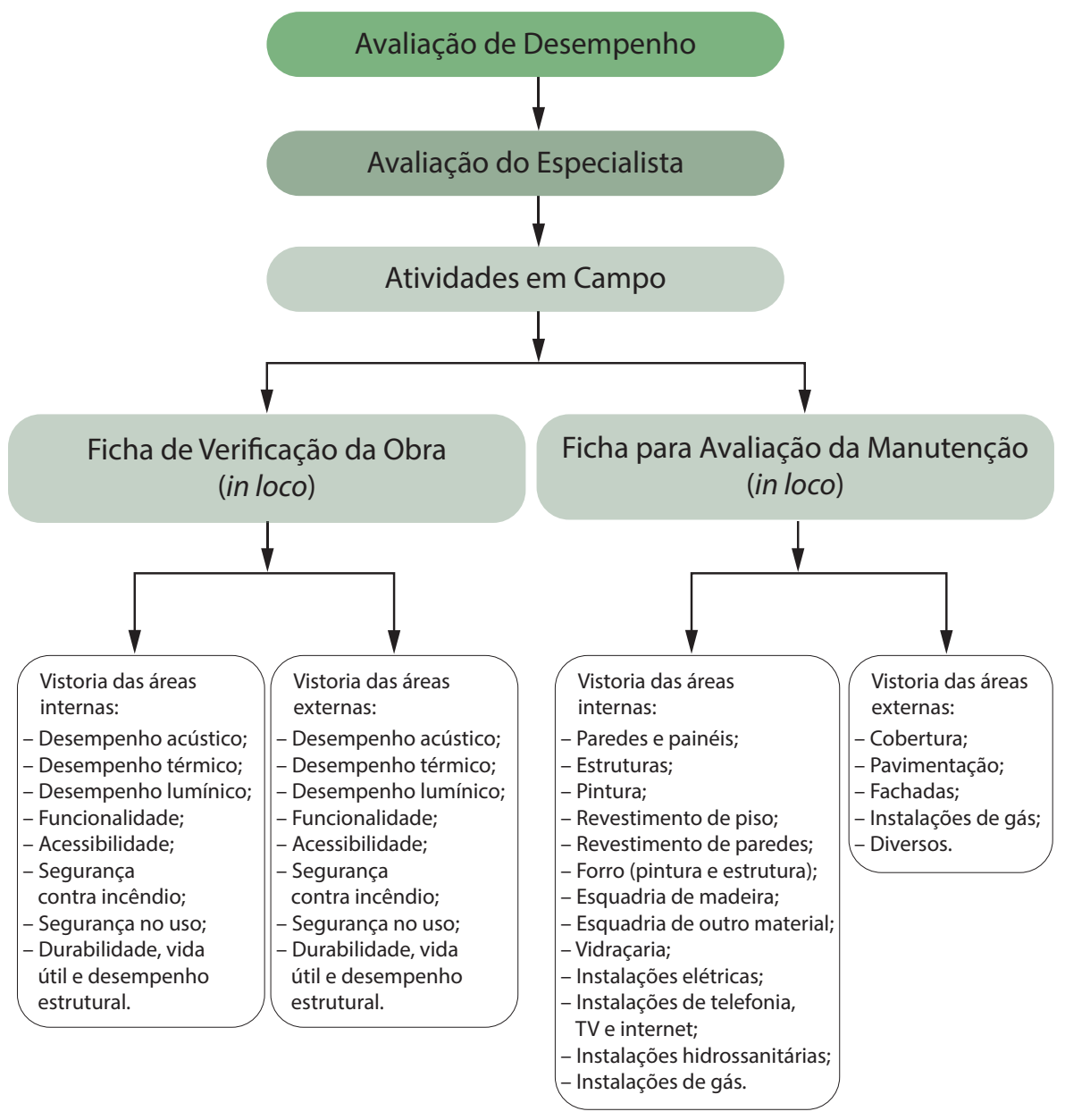

Figura 1. Conjunto de instrumentos propostos e aplicados em campo (in loco).

\section{Caracterização do Conjunto Habitacional Avaliado e da Aplicação dos Instrumentos em Campo}

Os instrumentos de Avaliação Pós-Ocupação (APO) foram aplicados em um conjunto habitacional, cujo projeto iniciou em 2011 e a construção 
foi concluída em 2013, em um município de pequeno porte, localizado no interior do estado de São Paulo. Para a análise de desempenho das unidades habitacionais, considerando que essas edificaçóes foram construídas por um único empreendedor, a partir da aplicação de uma única tecnologia inovadora, com produção seriada aplicada a $100 \%$ das unidades, nas quais poderão ser identificadas falhas sistemáticas, tanto originárias do projeto como do processo de construção, considerou-se que um número reduzido de amostra seria suficiente para evidenciar essas falhas. Assim, foram avaliadas 19 unidades habitacionais de um total de 336 habitaçóes térreas unifamiliares isoladas.

Cada unidade está disposta em um terreno de aproximadamente $210 \mathrm{~m}^{2}$ e possui uma área construída de $52,36 \mathrm{~m}^{2}$, com três dormitórios, sala de estar, cozinha e banheiro. A construção, além das paredes produzidas com a tecnologia avaliada, é composta por uma cobertura de telhas cerâmicas, estruturada com tesouras de madeira; forro de laje pré-moldada; esquadrias de alumínio e folhas das portas de madeira; revestimento cerâmico no piso de todos os ambientes e nas paredes do banheiro. Externamente, foi entregue uma calçada de aproximadamente 1,0 m de largura, circundando a edificação, e próximo à porta de acesso à cozinha, foi disposta uma área descoberta para tanque e para um abrigo para dois botijóes de gás (GLP).

Os dados obtidos com a aplicação em campo (in loco) dos instrumentos intitulados "Ficha de Verificação da Obra" e "Ficha de Avaliação da Manutenção" são apresentados a seguir. Os levantamentos foram realizados nos dias 12 e 13 de junho de 2015 e alguns dados foram complementados com uma nova ida a campo em 06 de agosto de 2016. As duas seçôes seguintes caracterizam sinteticamente cada instrumento e comentam os resultados encontrados.

\section{Resultados da Aplicação da Ficha de Verificação da Obra}

As Fichas de Verificação da Obra averiguam aspectos de desempenho da unidade habitacional que se referem tanto às áreas internas como à área externa. As fichas foram estruturadas a partir de critérios estabelecidos na NBR 15575 (ABNT, 2013), e as respostas devem se enquadrar na seguinte gradação proposta pela metodologia: A - Atende, quando o critério analisado 
foi atendido na inspeção realizada; NA - Não Atende, quando o critério não foi atendido; NSA - Não Se Aplica ao caso inspecionado, quando o item for destinado a uma tipologia construtiva diferente; NV - Não Verificado, quando não foi possível verificar o item na inspeção realizada.

\subsection{Verificação de Áreas Internas}

O método proposto, por meio da Ficha de Verificação da Obra, leva, inicialmente, à avaliação de desempenho das áreas internas da edificação. Os itens verificados foram:

- Desempenho acústico e lumínico;

- Funcionalidade;

- Acessibilidade;

- Segurança contra incêndio;

- Segurança no uso;

- Durabilidade, vida útil e segurança estrutural.

O desempenho térmico não faz parte da ficha para verificação de desempenho em campo, devido à falta de efetividade de mediçôes realizadas pontualmente, isto é, em um período específico, como seria o caso da medição no dia da aplicação do instrumento em campo.

Quanto à medição do desempenho acústico, a NBR 15575 (ABNT, 2013) estabelece valores mínimos de isolação sonora dos elementos de vedação, mas não os parâmetros de níveis de ruído interno, especificado na NBR 10152 (ABNT, 1992). As mediçóes de isolação sonora podem ser feitas em qualquer horário, desde que não perturbe muito a vizinhança, pois, para tanto, devem ser gerados ruídos de mais de $80 \mathrm{~dB}$ durante as mediçôes. No entanto, essa medição não pôde ser realizada no estudo de caso devido à falta de equipamentos adequados e treinamento da equipe técnica para tal atividade.

A medição em campo do desempenho lumínico, por sua vez, foi realizada e verificou o atendimento aos critérios mínimos. Assim como está previsto no critério 13.2.3 da NBR 15575-1 (ABNT, 2013), a determinação do Fator de Luz Diurna foi resultado da relação entre a iluminância medida dentro do ambiente e a iluminância medida fora do ambiente, sem a incidência da luz solar direta sobre os sensores em ambos os casos. 
Tabela 1. Verificação de área interna: desempenho lumínico.

\begin{tabular}{lccccc}
\hline \multicolumn{1}{c}{ Desempenho Lumínico } & Requisito & A & NA & NSA & NV \\
\hline $\begin{array}{l}\text { Os dormitórios têm Fator de Luz Diurna } \\
\text { igual ou superior a 0,5\% }\end{array}$ & (obrigatório) & $\begin{array}{c}17 \\
(100 \%)\end{array}$ & 0 & 0 & 2 \\
\hline $\begin{array}{l}\text { A sala de estar/ jantar tem Fator de Luz } \\
\text { Diurna igual ou superior a 0,5\% }\end{array}$ & (obrigatório) & $\begin{array}{c}19 \\
(100 \%)\end{array}$ & 0 & 0 & 0 \\
\hline $\begin{array}{l}\text { A cozinha tem Fator de Luz Diurna igual } \\
\text { ou superior a 0,5\% }\end{array}$ & (obrigatório) & $\begin{array}{c}19 \\
(100 \%)\end{array}$ & 0 & 0 & 0 \\
\hline $\begin{array}{l}\text { Banheiro tem luz natural } \\
\text { (facultativo) }\end{array}$ & $\begin{array}{c}19 \\
(100 \%)\end{array}$ & 0 & 0 & 0 \\
\hline $\begin{array}{l}\text { Todos os dormitórios possuem } \\
\text { mecanismos de controle de iluminância } \\
\text { integrado aos caixilhos }\end{array}$ & (facultativo) & $\begin{array}{c}18 \\
(100 \%)\end{array}$ & 0 & 0 & 1 \\
\hline
\end{tabular}

A: Atende ao requisito de desempenho; NA: Não Atende ao requisito de desempenho; NSA: Não se aplica ao empreendimento inspecionado; NV: Não verificado.

Todos os cômodos em que a medição foi realizada atenderam às condiçôes mínimas de desempenho lumínico, sejam elas ligadas a requisitos obrigatórios ou facultativos. Cabe observar que as mediçôes de iluminância foram realizadas sequencialmente, uma vez que não havia condiçóes operacionais para medição simultânea interna e externa. Assim, procedeu-se à medição da iluminância no interior dos cômodos, seguida da medição no exterior, à sombra, para cada unidade habitacional.

A verificação da Funcionalidade das áreas internas trata da altura do pé-direito dos ambientes da edificação, adotando como critério alguns valores mínimos, conforme indicados na Tabela 2 . Nessa tabela também estão descritos os resultados de cada item da ficha de funcionalidade observados na aplicação em campo.

Tabela 2. Verificação de área interna: funcionalidade.

\begin{tabular}{|c|c|c|c|c|c|}
\hline Funcionalidade & Requisito & A & NA & NSA & NV \\
\hline Dormitórios e sala têm pé-direito $>=2,50 \mathrm{~m}$ & (obrigatório) & $\begin{array}{c}19 \\
(100 \%)\end{array}$ & 0 & 0 & 0 \\
\hline $\begin{array}{l}\text { Cozinha e área de serviço tem pé-direito } \\
>=2,50 \mathrm{~m}\end{array}$ & (obrigatório) & $\begin{array}{c}19 \\
(100 \%)\end{array}$ & 0 & 0 & 0 \\
\hline Banheiro tem pé-direito $>=2,30 \mathrm{~m}$ & (obrigatório) & $\begin{array}{c}19 \\
(100 \%)\end{array}$ & 0 & 0 & 0 \\
\hline
\end{tabular}


Todos os cômodos atenderam às condiçôes de funcionalidade obrigatórias verificadas, relacionadas ao pé-direito nos cômodos. Entretanto seria recomendável, adicionalmente, incluir a verificação de índices de obstrução, ou seja, das áreas necessárias em cada ambiente para abrigar mobiliário, equipamentos com circulação e espaços para usos seguro e confortável.

A verificação de Acessibilidade observa as condiçôes dos vãos livres para circulação em toda a edificação. A Tabela 3 apresenta o item da ficha de verificação da acessibilidade e os resultados da vistoria em campo realizada.

Tabela 3. Verificação de área interna: acessibilidade.

\begin{tabular}{cccccc}
\hline Acessibilidade & Requisito & A & NA & NSA & NV \\
\hline Todas as portas têm vãos livres $>=80 \mathrm{~cm}$ & (facultativo) & $\begin{array}{c}3 \\
(16 \%)\end{array}$ & $\begin{array}{c}16 \\
(84 \%)\end{array}$ & 0 & 0 \\
\hline
\end{tabular}

Esse requisito único de acessibilidade é facultativo e tem como objetivo verificar a possibilidade de passagem de pessoas com dificuldade de mobilidade, como usuários de cadeiras de rodas. Três das casas inspecionadas eram originalmente acessíveis e apenas elas tinham portas mais largas. Nos demais casos, verificou-se que havia limitaçóes à acessibilidade e que, entre as unidades não designadas como acessíveis, existiam pessoas com mobilidade reduzida.

Os itens da Segurança contra incêndio estão relacionados aos dispositivos das instalaçóes de gás, local dos botijóes e aos pontos de tomadas. A Tabela 4 apresenta os itens e as frequências encontradas na vistoria de campo. Com relação à instalação de gás, que serve unicamente à alimentação do fogão na cozinha, uma tubulação de cobre embutida nas paredes transporta o gás de botijão, que está num abrigo externo com espaço para dois botijóes de $13 \mathrm{~kg}$, localizado ao lado do tanque de lavar roupas, até o ponto na cozinha, ao lado da pia. Contudo, embora o projeto esteja em concordância com as especificaçóes exigidas por norma, em muitas das unidades habitacionais inspecionadas foram identificados problemas relacionados a esse subsistema. 
Tabela 4. Verificação de área interna: segurança contra incêndio.

\begin{tabular}{|c|c|c|c|c|c|}
\hline Segurança Contra Incêndio & Requisito & A & NA & NSA & NV \\
\hline $\begin{array}{l}\text { Instalações de gás possuem dispositivos de } \\
\text { segurança que garantam estanqueidade }\end{array}$ & (obrigatório) & $\begin{array}{c}11 \\
(60 \%)\end{array}$ & $\begin{array}{c}8 \\
(42 \%)\end{array}$ & 0 & 0 \\
\hline $\begin{array}{l}\text { Não existem botijões de gás dentro da } \\
\text { residência }\end{array}$ & (obrigatório) & $\begin{array}{c}5 \\
(26 \%)\end{array}$ & $\begin{array}{c}14 \\
(74 \%)\end{array}$ & 0 & 0 \\
\hline $\begin{array}{l}\text { Os pontos de tomada elétrica destinados a } \\
\text { alimentar mais de um equipamento devem } \\
\text { ser providos com quantidade adequada de } \\
\text { tomadas, sem "tês" ou benjamins. } \\
\text { Este critério deve ser verificado em projeto } \\
\text { a fim de investigar se há o atendimento ao } \\
\text { número mínimo de tomadas especificado } \\
\text { na NBR } 5410\end{array}$ & (obrigatório) & $\begin{array}{c}11 \\
(58 \%)\end{array}$ & $\begin{array}{c}8 \\
(42 \%)\end{array}$ & 0 & 0 \\
\hline $\begin{array}{l}\text { Componentes elétricos com partes móveis } \\
\text { devem ser inspecionados quanto ao estado } \\
\text { dos contatos }\end{array}$ & (facultativo) & $\begin{array}{c}19 \\
(100 \%)\end{array}$ & 0 & 0 & 0 \\
\hline
\end{tabular}

Em 32\% dos casos, não havia dispositivos que garantissem a estanqueidade da instalação, como a mangueira flexível apropriada para conexão. Em 74\% dos casos, o botijão de gás encontrava-se no interior do ambiente da cozinha, apesar de haver um abrigo adequado para esse elemento na parte externa da unidade. Alguns moradores, quando questionados sobre esse procedimento, alegaram ou ainda queixaram-se da localização projetada para a saída do gás e ligação do fogão, próximo a uma corrente de ar, proporcionada pela porta de acesso externo, que apagava as bocas acesas do fogáo. Outros revelaram o receio de furto do botijão deixado no abrigo, que é aberto. O condicionamento de botijōes de gás no interior da habitaçáo tem impacto negativo relevante na segurança contra incêndio, pois aumenta o risco do vazamento de GLP no interior da unidade habitacional, gás inflamável que pode causar incêndio, explosão e a intoxicação por inalação. Além disso, há uma grande frequência de uso de "tês" e benjamins nas tomadas elétricas, que podem sobreaquecer e sobrecarregar as instalaçôes elétricas, e eventualmente iniciar incêndios.

A verificação da Segurança no uso contém dois itens obrigatórios, relativos ao piso interno. Como aponta a Tabela 5, apenas a presença indesejável de desníveis acima de $5 \mathrm{~mm}$ foi observada em dois casos (10\%). 
Devido às características observadas em campo, presume-se que essa ocorrência se deva à falha de execução do piso interno, especificamente, no desnível do piso do banheiro.

Tabela 5. Verificação de área interna: segurança no uso.

\begin{tabular}{lcccrr}
\hline \multicolumn{1}{c}{ Segurança no Uso } & Requisito & A & NA & NSA & NV \\
\hline $\begin{array}{l}\text { O piso interno não apresenta rugosidade } \\
\text { excessiva, arestas contundentes ou } \\
\text { fragmentos perfurantes ou contundentes }\end{array}$ & (obrigatório) & $\begin{array}{c}19 \\
(100 \%)\end{array}$ & 0 & 0 & 0 \\
\hline $\begin{array}{l}\text { O acabamento de pisos internos não tem } \\
\text { desníveis superiores a 5mm }\end{array}$ & (obrigatório) & $\begin{array}{c}17 \\
(90 \%)\end{array}$ & $\begin{array}{c}2 \\
(10 \%)\end{array}$ & 0 & 0 \\
\hline
\end{tabular}

A verificação da Durabilidade, vida útil e desempenho estrutural está relacionada ao funcionamento de ralos, à presença de fissuras ou deformaçóes em elementos estruturais, ao descolamento ou exposição de armaduras, aos sinais de umidade, integridade de rejuntamentos e selantes de juntas, ao funcionamento de janelas e à corrosão em peças metálicas. Em relação ao desempenho geral do sistema de vedação analisado, quanto à durabilidade e vida útil, a avaliação foi positiva, como pode ser visto na Tabela 6 , em que os casos nos quais os requisitos verificados náo foram atendidos não ultrapassam $10 \%$ do total. De fato, o maior número de problemas não se relaciona ao sistema, mas sim decorre da inadequação das interfaces com outros componentes e da baixa qualidade deles, como observado nas esquadrias, nos revestimentos cerâmicos e na impermeabilização.

Dentre os itens de durabilidade, vida útil e desempenho estrutural verificados, destacam-se alguns problemas estruturais, como fissuras superiores a $0,6 \mathrm{~mm}(16 \%)$ na estrutura, deformação do esquadro suficiente para dificultar o funcionamento de portas e janelas (32\%) e fissuras nos elementos de vedação (26\%). Além desses casos, também foram apontadas: falta de aderência de revestimentos cerâmicos (10\%), sinais de umidade no piso do banheiro (42\%) e umidade na base das paredes (21\%). 
Tabela 6. Verificação de área interna: durabilidade, vida útil e desempenho estrutural.

\begin{tabular}{|c|c|c|c|c|c|}
\hline $\begin{array}{l}\text { Durabilidade, Vida Útil e } \\
\text { Desempenho Estrutural }\end{array}$ & $\begin{array}{l}\text { Nível de } \\
\text { importância }\end{array}$ & A & NA & NSA & NV \\
\hline Ralos e grelhas estão limpos e funcionando & (obrigatório) & $\begin{array}{c}18 \\
(95 \%) \\
\end{array}$ & $\begin{array}{c}1 \\
(5 \%) \\
\end{array}$ & 0 & 0 \\
\hline $\begin{array}{l}\text { Os elementos estruturais não apresentam } \\
\text { fissuras com aberturas superiores a 0,6 mm. }\end{array}$ & (obrigatório) & $\begin{array}{c}16 \\
(84 \%)\end{array}$ & $\begin{array}{c}3 \\
(16 \%)\end{array}$ & 0 & 0 \\
\hline $\begin{array}{l}\text { A deformação da estrutura não impede o } \\
\text { livre funcionamento de componentes da } \\
\text { edificação (portas e janelas) nem repercute no } \\
\text { funcionamento das instalações. }\end{array}$ & (obrigatório) & $\begin{array}{c}13 \\
(68 \%)\end{array}$ & $\begin{array}{c}6 \\
(32 \%)\end{array}$ & 0 & 0 \\
\hline $\begin{array}{l}\text { A estrutura não está proporcionando } \\
\text { insegurança aos usuários pelas deformações } \\
\text { de quaisquer elementos da edificação. }\end{array}$ & (obrigatório) & $\begin{array}{c}19 \\
(100 \%)\end{array}$ & 0 & 0 & 0 \\
\hline $\begin{array}{l}\text { O sistema estrutural não ocasiona } \\
\text { deslocamentos ou fissuras excessivas aos } \\
\text { elementos de construção vinculados ao } \\
\text { sistema estrutural }\end{array}$ & (obrigatório) & $\begin{array}{c}18 \\
(95 \%)\end{array}$ & 1 & 0 & 0 \\
\hline $\begin{array}{l}\text { Não há descolamento do cobrimento de } \\
\text { concreto das armaduras dos elementos } \\
\text { estruturais }\end{array}$ & (obrigatório) & $\begin{array}{c}19 \\
(100 \%)\end{array}$ & 0 & 0 & 0 \\
\hline $\begin{array}{l}\text { Não há armadura exposta nos elementos } \\
\text { estruturais (vigas, lajes e pilares) }\end{array}$ & (obrigatório) & $\begin{array}{c}19 \\
(100 \%)\end{array}$ & 0 & 0 & 0 \\
\hline Não há sinais de eflorescência na edificação. & (obrigatório) & $\begin{array}{c}18 \\
(95 \%)\end{array}$ & 0 & $\begin{array}{c}1 \\
(5 \%)\end{array}$ & 0 \\
\hline $\begin{array}{l}\text { Não há fissuras nos elementos de vedação } \\
\text { (paredes e ou divisórias) }\end{array}$ & (obrigatório) & $\begin{array}{c}14 \\
(74 \%)\end{array}$ & $\begin{array}{c}5 \\
(26 \%)\end{array}$ & 0 & 0 \\
\hline $\begin{array}{l}\text { Os elementos estruturais de vedação, em que } \\
\text { há peças suspensas, não apresentam fissuras, } \\
\text { deslocamentos horizontais e lascamentos, } \\
\text { ou ainda, arrancamento dos dispositivos de } \\
\text { fixação nem seu esmagamento. }\end{array}$ & (obrigatório) & $\begin{array}{c}16 \\
(84 \%)\end{array}$ & 0 & $\begin{array}{c}3 \\
(16 \%)\end{array}$ & 0 \\
\hline $\begin{array}{l}\text { Os revestimentos das vedações não } \\
\text { apresentam falta de aderência com o } \\
\text { substrato }\end{array}$ & (obrigatório) & $\begin{array}{c}17 \\
(89 \%)\end{array}$ & $\begin{array}{c}2 \\
(11 \%)\end{array}$ & 0 & 0 \\
\hline $\begin{array}{l}\text { Não há sinais de umidade nos pisos da } \\
\text { edificação. }\end{array}$ & (obrigatório) & $\begin{array}{c}11 \\
(58 \%)\end{array}$ & $\begin{array}{c}8 \\
(42 \%)\end{array}$ & 0 & 0 \\
\hline $\begin{array}{l}\text { Não há sinais de umidade na base das } \\
\text { paredes. }\end{array}$ & (obrigatório) & $\begin{array}{c}15 \\
(79 \%)\end{array}$ & $\begin{array}{c}4 \\
(21 \%)\end{array}$ & 0 & 0 \\
\hline $\begin{array}{l}\text { Há integridade nos rejuntamentos internos } \\
\text { dos pisos, paredes, peitoris, soleiras, ralos, } \\
\text { peças sanitárias, bordas de banheiras e outros } \\
\text { elementos. }\end{array}$ & (obrigatório) & $\begin{array}{c}18 \\
(95 \%)\end{array}$ & $\begin{array}{c}1 \\
(5 \%)\end{array}$ & 0 & 0 \\
\hline
\end{tabular}


Tabela 6. Continuação.

\begin{tabular}{lcccrr}
\hline \multicolumn{1}{c}{$\begin{array}{l}\text { Durabilidade, Vida Útil e } \\
\text { Desempenho Estrutural }\end{array}$} & $\begin{array}{c}\text { Nível de } \\
\text { importância }\end{array}$ & A & NA & NSA & NV \\
\hline $\begin{array}{l}\text { Há integridade dos selantes das juntas entre } \\
\text { Os painéis estruturais }\end{array}$ & (obrigatório) & $\begin{array}{c}19 \\
(100 \%)\end{array}$ & 0 & 0 & 0 \\
\hline $\begin{array}{l}\text { Não há sinais visíveis de corrosão na ligação } \\
\text { metálica dos painéis. }\end{array}$ & (obrigatório) & $\begin{array}{c}19 \\
(100 \%)\end{array}$ & 0 & 0 & 0 \\
\hline
\end{tabular}

A avaliaçáo geral das áreas internas corresponde ao balanço dos requisitos obrigatórios e facultativos atendidos e não atendidos relativos aos itens de verificação, relacionados direta ou indiretamente ao desempenho das áreas internas das edificações vistoriadas. O quadro geral desse balanço, apresentado na Tabela 7, quantifica e classifica os itens analisados por tipo de requisito de desempenho e tipo de exigência de atendimento.

Tabela 7. Quadro geral de avaliação das áreas internas.

\begin{tabular}{|c|c|c|c|c|}
\hline Desempenho lumínico & A & NA & NSA & NV \\
\hline Obrigatórios & $55(100 \%)$ & 0 & 0 & 2 \\
\hline Facultativos & $37(100 \%)$ & 0 & 0 & 1 \\
\hline Funcionalidade & A & NA & NSA & NV \\
\hline Obrigatórios & $57(100 \%)$ & 0 & 0 & 0 \\
\hline Acessibilidade & A & NA & NSA & NV \\
\hline Facultativos & $\begin{array}{c}3 \\
(16 \%) \\
\end{array}$ & $\begin{array}{c}16 \\
(84 \%) \\
\end{array}$ & 0 & 0 \\
\hline Segurança contra incêndio & A & NA & NSA & NV \\
\hline Obrigatórios & $\begin{array}{c}27 \\
(47 \%) \\
\end{array}$ & $\begin{array}{c}28 \\
(50 \%) \\
\end{array}$ & $\begin{array}{c}2 \\
(3 \%) \\
\end{array}$ & 0 \\
\hline Facultativos & $19(100 \%)$ & 0 & 0 & 0 \\
\hline Segurança no uso & A & NA & NSA & NV \\
\hline Obrigatórios & $\begin{array}{c}36 \\
(95 \%) \\
\end{array}$ & $\begin{array}{c}2 \\
(5 \%) \\
\end{array}$ & 0 & 0 \\
\hline $\begin{array}{l}\text { Vida útil, durabilidade e } \\
\text { desempenho estrutural }\end{array}$ & A & NA & NSA & NV \\
\hline Obrigatórios & $266(88 \%)$ & $\begin{array}{c}31 \\
(10 \%) \\
\end{array}$ & $\begin{array}{c}4 \\
(1 \%) \\
\end{array}$ & 3 \\
\hline
\end{tabular}


Dos requisitos verificados, as situaçôes mais críticas observadas estão relacionadas às exigências de atendimento obrigatório em segurança contra incêndio, com problemas nas instalaçóes de gás e nas instalações elétricas, e à exigência facultativa de acessibilidade, relacionada à largura das portas nas casas que, a princípio, não seriam designadas para pessoas com dificuldade de mobilidade, mas eventualmente o são. Nos demais requisitos, a avaliação foi satisfatória. No entanto, verificou-se, nos requisitos de "vida útil, durabilidade e desempenho estrutural”, alguns problemas construtivos nas paredes e pisos, relacionados principalmente a interfaces com os demais componentes e com a execução, que prejudicaram o desempenho geral das unidades no quesito em questão.

Cabe ressaltar que, para atender a necessidade de uma avaliação integrada, os requisitos de desempenho até aqui verificados precisam ser complementados pelos resultados obtidos na análise das documentaçóes (Capítulo 8), no questionário ao morador (Capítulo 10) e na avaliação da manutenibilidade, apresentada ainda neste capítulo, na seção 4 .

\subsection{Verificação de Áreas Externas}

Além da verificação de desempenho das áreas internas, o instrumento ainda inclui a análise das áreas externas à edificação, que se aplicam principalmente a casos de edifícios multifamiliares que se organizam em forma de condomínio e possuem áreas de uso comum. Assim, a aplicabilidade desses itens e a abrangência da avaliação são reduzidas no caso em que o empreendimento apresenta unidades unifamiliares isoladas.

Outra limitação para o preenchimento das fichas decorreu da orientação para se considerar apenas a verificação das condições de elementos e sistemas que foram entregues, ou seja, que constam do projeto e foram implementados no empreendimento pela companhia estadual e a prefeitura municipal. Assim, problemas resultantes de intervençôes dos moradores foram descricionados e considerados na análise dos resultados, porém, não foram contabilizados.

Os requisitos de desempenho ambiental e funcionalidade não possuem fichas com aspectos a serem verificados nas áreas externas ou comuns. Os demais itens como acessibilidade, segurança contra incêndio, segurança no uso, durabilidade, vida útil e desempenho estrutural foram verificados, e os resultados são apresentados nas Tabelas 8 a 12 . 
A verificação da acessibilidade das áreas externas evidenciou a inadequação do formulário proposto para as situaçôes de unidades habitacionais unifamiliares isoladas ou geminadas, o que dificultou uma análise quantitativa de vários requisitos específicos não relacionados a áreas comuns. Todavia, dois itens puderam ser verificados, como demonstra a Tabela 8. Observou-se que $47 \%$ das unidades apresentam soleiras com desníveis superiores a $5 \mathrm{~mm}$ em seu acesso para o interior da edificação.

Tabela 8. Verificação da área externa: acessibilidade.

\begin{tabular}{|c|c|c|c|c|c|}
\hline Acessibilidade & Requisito & A & NA & NSA & NV \\
\hline $\begin{array}{l}\text { Todos os vãos de passagem da rua até as } \\
\text { portas da unidade têm largura igual ou } \\
\text { superior a } 0,8 \mathrm{~m}\end{array}$ & (obrigatório) & $\begin{array}{c}18 \\
(95 \%)\end{array}$ & $\begin{array}{c}1 \\
(5 \%)\end{array}$ & 0 & 0 \\
\hline $\begin{array}{l}\text { Soleiras têm desnível igual ou inferior } \\
\text { a } 5 \mathrm{~mm} \text { no acesso do interior às áreas } \\
\text { comuns }\end{array}$ & (obrigatório) & 0 & 0 & $\begin{array}{c}19 \\
(100 \%)\end{array}$ & 0 \\
\hline $\begin{array}{l}\text { Soleiras têm desnível igual ou inferior } \\
\text { a } 5 \mathrm{~mm} \text { no acesso do exterior às áreas } \\
\text { comuns }\end{array}$ & (obrigatório) & 0 & 0 & $\begin{array}{c}19 \\
(100 \%)\end{array}$ & 0 \\
\hline $\begin{array}{l}\text { Soleiras têm desnível igual ou inferior a } \\
5 \mathrm{~mm} \text { no acesso às áreas comuns }\end{array}$ & (facultativo) & 0 & 0 & $\begin{array}{c}19 \\
(100 \%)\end{array}$ & 0 \\
\hline $\begin{array}{l}\text { Soleiras têm desnível igual ou inferior a } \\
5 \mathrm{~mm} \text { no acesso às unidades habitacionais }\end{array}$ & (facultativo) & 0 & $\begin{array}{c}19 \\
(100 \%)\end{array}$ & 0 & 0 \\
\hline
\end{tabular}

Para realizar a verificação da passagem da rua até a porta da unidade habitacional, considerou-se a largura do caminho entre a calçada e a entrada da unidade habitacional. Esse item não foi atendido em um caso, devido a intervençóes realizadas pelo morador no interior do lote. No projeto, o desnível entre o piso interno da unidade e o piso externo do radier é de, no mínimo, $20 \mathrm{~mm}$, e a medição realizada na vistoria confirma o não atendimento ao último item da ficha.

No caso dos requisitos relacionados à Segurança contra Incêndio, compreendeu-se que eles não eram aplicáveis ao estudo em questão, pois se tratam de observaçóes para as áreas de uso comum, como pode ser visto na Tabela 9. 
Tabela 9. Verificação de área externa: segurança contra Incêndio.

\begin{tabular}{|c|c|c|c|c|c|}
\hline Segurança contra incêndio & Requisito & A & NA & NSA & NV \\
\hline $\begin{array}{l}\text { Corredores e escadas não têm obstruções e } \\
\text { reduções na largura efetiva. }\end{array}$ & (obrigatório) & 0 & 0 & $\begin{array}{c}19 \\
(100 \%)\end{array}$ & 0 \\
\hline $\begin{array}{l}\text { As escadas têm corrimãos adequados (contínuos e } \\
\text { com altura de } 92 \mathrm{~cm} \text { ). }\end{array}$ & (obrigatório) & 0 & 0 & $\begin{array}{c}19 \\
(100 \%)\end{array}$ & 0 \\
\hline $\begin{array}{l}\text { Os extintores, hidrantes e alarmes estão } \\
\text { devidamente sinalizados. }\end{array}$ & (obrigatório) & 0 & 0 & $\begin{array}{c}19 \\
(100 \%)\end{array}$ & 0 \\
\hline $\begin{array}{l}\text { Locais de risco, como cabines de força e centrais de } \\
\text { gás, estão devidamente sinalizados. }\end{array}$ & (obrigatório) & 0 & 0 & $\begin{array}{c}19 \\
(100 \%)\end{array}$ & 0 \\
\hline $\begin{array}{l}\text { Há uma luminária de emergência a cada } 7,5 \mathrm{~m} \text { de } \\
\text { raio e todas funcionam. }\end{array}$ & (obrigatório) & 0 & 0 & $\begin{array}{c}19 \\
(100 \%) \\
\end{array}$ & 0 \\
\hline \multicolumn{6}{|c|}{ Extintores portáteis - Instalação } \\
\hline $\begin{array}{l}\text { A alça de manuseio está, no máximo, a 1,60 m do } \\
\text { piso acabado e a parte inferior está acima de } 10 \mathrm{~cm} \\
\text { do piso acabado. }\end{array}$ & (obrigatório) & 0 & 0 & $\begin{array}{c}19 \\
(100 \%)\end{array}$ & 0 \\
\hline Está visível e não obstruído. & (obrigatório) & 0 & 0 & $\begin{array}{c}19 \\
(100 \%)\end{array}$ & 0 \\
\hline $\begin{array}{l}\text { Está protegido de intempéries e danos físicos em } \\
\text { potencial. }\end{array}$ & (obrigatório) & 0 & 0 & $\begin{array}{c}19 \\
(100 \%)\end{array}$ & 0 \\
\hline É fácil remover do suporte. & (obrigatório) & 0 & 0 & $\begin{array}{c}19 \\
(100 \%)\end{array}$ & 0 \\
\hline Não está instalado em escadas. & (obrigatório) & 0 & 0 & $\begin{array}{c}19 \\
(100 \%)\end{array}$ & 0 \\
\hline \multicolumn{6}{|c|}{ Extintores portáteis - Distribuição } \\
\hline $\begin{array}{l}\text { Classe A: distância máxima entre extintores é de } \\
25 \mathrm{~m} .\end{array}$ & (obrigatório) & 0 & 0 & $\begin{array}{c}19 \\
(100 \%)\end{array}$ & 0 \\
\hline $\begin{array}{l}\text { Classes BC: a distância máxima entre extintores é de } \\
15 \text { m. }\end{array}$ & (obrigatório) & 0 & 0 & $\begin{array}{c}19 \\
(100 \%)\end{array}$ & 0 \\
\hline $\begin{array}{l}\text { Hidrantes ou mangotinhos e seus acessórios: } \\
\text { mangueiras e seus abrigos; esguichos, bombas } \\
\text { e registro de recalque estão em boas condições } \\
\text { visuais e os pontos de hidrantes e/ou mangotinhos } \\
\text { estão montados com todos os materiais e acessórios } \\
\text { previstos e totalmente desobstruídos. }\end{array}$ & (obrigatório) & 0 & 0 & $\begin{array}{c}19 \\
(100 \%)\end{array}$ & 0 \\
\hline
\end{tabular}

Novamente, como pode ser visto na Tabela 10, a maioria dos requisitos relacionados à Segurança no uso não são aplicáveis (NSA) ao levantamento realizado em unidades habitacionais isoladas, pois os itens da ficha são orientados para avaliação de edifícios habitacionais multifamiliares. 
Tabela 10. Verificação de área externa: segurança no uso.

\begin{tabular}{|c|c|c|c|c|c|}
\hline Segurança no Uso & Requisito & A & NA & NSA & NV \\
\hline $\begin{array}{l}\text { O piso externo não tem desníveis superiores } \\
\text { a } 5 \mathrm{~mm} \text { e frestas superiores a } 4 \mathrm{~mm} \text {. }\end{array}$ & (obrigatório) & $\begin{array}{c}18 \\
(95 \%)\end{array}$ & $\begin{array}{c}1 \\
(5 \%)\end{array}$ & 0 & 0 \\
\hline $\begin{array}{l}\text { O piso externo não apresenta rugosidade } \\
\text { excessiva ou arestas contundentes que } \\
\text { tornem impraticável o apoio direto dos pés } \\
\text { desnudos ou possam ocasionar lesões. }\end{array}$ & (obrigatório) & $\begin{array}{c}19 \\
(100 \%)\end{array}$ & 0 & 0 & 0 \\
\hline $\begin{array}{l}\text { Pisos e espelhos das escadas têm dimensões } \\
\text { constantes em toda a escada. }\end{array}$ & (obrigatório) & & 0 & $\begin{array}{c}19 \\
(100 \%)\end{array}$ & 0 \\
\hline $\begin{array}{l}\text { O SPDA apresenta integridade da captação } \\
\text { ao aterramento. }\end{array}$ & (obrigatório) & 0 & 0 & $\begin{array}{c}19 \\
(100 \%)\end{array}$ & 0 \\
\hline $\begin{array}{l}\text { A altura mínima de guarda-corpos, } \\
\text { considerada entre o piso acabado e a parte } \\
\text { superior do peitoril, é de } 15 \text { m ou 1,30 m, } \\
\text { conforme situação. }\end{array}$ & (obrigatório) & 0 & 0 & $\begin{array}{c}19 \\
(100 \%)\end{array}$ & 0 \\
\hline $\begin{array}{l}\text { A distância entre perfis do gradil de guarda- } \\
\text { corpos (vão de luz) é menor ou igual a } 11 \mathrm{~cm} \text {. }\end{array}$ & (obrigatório) & 0 & 0 & $\begin{array}{c}19 \\
(100 \%)\end{array}$ & 0 \\
\hline
\end{tabular}

Apenas dois itens, relativos à condição do piso externo, puderam ser avaliados. Nestes, o piso do radier, construído ao redor de toda casa com largura de 1,0 m, apresentou, em uma das amostras, frestas maiores que as admissíveis.

$\mathrm{Na}$ avaliação da Durabilidade, vida útil e desempenho estrutural, alguns itens não foram verificados (NV) em todos os casos, em função de circunstâncias específicas do trabalho de campo, que impediram o levantamento pelos pesquisadores.

Quanto ao preenchimento da ficha, houve uma discussão em relação à necessidade de adequabilidade dos itens nela contidos, visando à uniformização da compreensão do seu conteúdo, em função de particularidades do sistema construtivo, como observadas no caso estudado, em que o sistema de vedação faz parte do sistema estrutural (Tabela 11).

O primeiro item dessa ficha (Tabela 11) trata do funcionamento de ralos, grelhas e canaletas. Como o projeto do empreendimento náo previa, em nenhum caso, tais recursos para drenagem de água no interior dos lotes, todos foram identificados como não se aplica (NSA). Contudo, cabe observar a existência de residências com algum desses elementos, decorrentes de alteraçôes realizadas por moradores. 
Tabela 11. Verificação de área externa: durabilidade, vida útil e desempenho estrutural.

\begin{tabular}{|c|c|c|c|c|c|}
\hline $\begin{array}{l}\text { Durabilidade, Vida Útil e } \\
\text { Desempenho Estrutural }\end{array}$ & Requisito & A & NA & NSA & NV \\
\hline $\begin{array}{l}\text { Ralos, grelhas, calhas e canaletas estão } \\
\text { limpos e funcionando. }\end{array}$ & (obrigatório) & 0 & 0 & $\begin{array}{c}18 \\
(100 \%)\end{array}$ & 1 \\
\hline $\begin{array}{l}\text { Há integridade estrutural dos componen- } \\
\text { tes, vedações e fixações da cobertura. }\end{array}$ & (obrigatório) & $\begin{array}{c}16 \\
(94 \%)\end{array}$ & $\begin{array}{c}1 \\
(6 \%)\end{array}$ & 0 & 2 \\
\hline $\begin{array}{l}\text { Os elementos estruturais não apresentam } \\
\text { fissuras com aberturas superiores a } 0.6 \mathrm{~mm} \text {. }\end{array}$ & (obrigatório) & $\begin{array}{c}15 \\
(88 \%) \\
\end{array}$ & $\begin{array}{c}2 \\
(12 \%) \\
\end{array}$ & 0 & 2 \\
\hline $\begin{array}{l}\text { A estrutura não está proporcionando } \\
\text { insegurança aos usuários pelas deforma- } \\
\text { ções de quaisquer elementos da edificação. }\end{array}$ & (obrigatório) & $\begin{array}{c}18 \\
(100 \%)\end{array}$ & 0 & 0 & 1 \\
\hline $\begin{array}{l}\text { O sistema estrutural não ocasiona } \\
\text { deslocamentos ou fissuras excessivas aos } \\
\text { elementos de construção vinculados. }\end{array}$ & (obrigatório) & $\begin{array}{c}17 \\
(100 \%)\end{array}$ & 0 & 0 & 2 \\
\hline $\begin{array}{l}\text { Não há fissura no encontro laje de piso ou } \\
\text { calçadas laterais e parede no pavimento } \\
\text { térreo (quando este não for pilotis). }\end{array}$ & (obrigatório) & $\begin{array}{c}15 \\
(88 \%)\end{array}$ & $\begin{array}{c}2 \\
(12 \%)\end{array}$ & 0 & 2 \\
\hline $\begin{array}{l}\text { Não há descolamento do cobrimento de } \\
\text { concreto das armaduras dos elementos } \\
\text { estruturais. }\end{array}$ & (obrigatório) & $\begin{array}{c}17 \\
(94 \%)\end{array}$ & $\begin{array}{c}1 \\
(6 \%)\end{array}$ & 0 & 1 \\
\hline $\begin{array}{l}\text { Não há armadura exposta nos elementos } \\
\text { estruturais (vigas, lajes e pilares). }\end{array}$ & (obrigatório) & $\begin{array}{c}18 \\
(100 \%) \\
\end{array}$ & 0 & 0 & 1 \\
\hline $\begin{array}{l}\text { Não há fissuras nos elementos de vedação } \\
\text { (paredes e/ou divisórias, muros). }\end{array}$ & (obrigatório) & $\begin{array}{c}13 \\
(76 \%) \\
\end{array}$ & $\begin{array}{c}4 \\
(24 \%) \\
\end{array}$ & 0 & 2 \\
\hline $\begin{array}{l}\text { Os revestimentos das vedações não } \\
\text { apresentam falta de aderência com o } \\
\text { substrato. }\end{array}$ & (obrigatório) & $\begin{array}{c}13 \\
(76 \%)\end{array}$ & $\begin{array}{c}4 \\
(24 \%)\end{array}$ & 0 & 2 \\
\hline $\begin{array}{l}\text { Não há sinais de umidade nos pisos da } \\
\text { edificação. }\end{array}$ & (obrigatório) & $\begin{array}{c}13 \\
(76 \%)\end{array}$ & $\begin{array}{c}4 \\
(24 \%)\end{array}$ & 0 & 2 \\
\hline $\begin{array}{l}\text { Não há sinais de umidades na base das } \\
\text { paredes. }\end{array}$ & (obrigatório) & $\begin{array}{c}13 \\
(72 \%) \\
\end{array}$ & $\begin{array}{c}5 \\
(28 \%) \\
\end{array}$ & 0 & 1 \\
\hline $\begin{array}{l}\text { Não há sinais de infiltração ou falhas de } \\
\text { impermeabilização nas áreas molhadas } \\
\text { externas, piscinas, reservatórios, } \\
\text { coberturas, jardins, espelhos d'água. }\end{array}$ & (obrigatório) & $\begin{array}{c}15 \\
(88 \%)\end{array}$ & $\begin{array}{c}2 \\
(12 \%)\end{array}$ & 0 & 2 \\
\hline $\begin{array}{l}\text { Há integridade nos rejuntamentos } \\
\text { externos de pisos, paredes, peitoris, } \\
\text { soleiras, ralos e outros elementos. }\end{array}$ & (obrigatório) & $\begin{array}{c}14 \\
(82 \%)\end{array}$ & $\begin{array}{c}3 \\
(18 \%)\end{array}$ & 0 & 2 \\
\hline $\begin{array}{l}\text { Há integridade dos selantes das juntas } \\
\text { entre os painéis estruturais. }\end{array}$ & (obrigatório) & $\begin{array}{c}17 \\
(100 \%)\end{array}$ & 0 & 0 & 2 \\
\hline $\begin{array}{l}\text { Não há sinais visíveis de corrosão na } \\
\text { ligação metálica dos painéis. }\end{array}$ & (obrigatório) & $\begin{array}{c}17 \\
(100 \%)\end{array}$ & 0 & 0 & 2 \\
\hline
\end{tabular}


A Tabela 12 apresenta os resultados da avaliaçáo geral das áreas externas, com as frequências do atendimento ou não aos itens de desempenho que constam das fichas de verificação.

Tabela 12. Quadro geral da avaliação das áreas externas.

\begin{tabular}{ccccc}
\hline Acessibilidade & A & NA & NSA & NV \\
\hline Obrigatórios & $\begin{array}{c}18 \\
(32 \%)\end{array}$ & $\begin{array}{c}1 \\
(2 \%)\end{array}$ & $\begin{array}{c}38 \\
(67 \%)\end{array}$ & 0 \\
\hline Facultativos & 0 & $\begin{array}{c}19 \\
(50 \%)\end{array}$ & $\begin{array}{c}19 \\
(50 \%)\end{array}$ & 0 \\
\hline Segurança contra incêndio & $\mathrm{A}$ & $\mathrm{NA}$ & $\mathrm{NSA}$ & $\mathrm{NV}$ \\
\hline Obrigatórios & 0 & 0 & $247(100 \%)$ & 0 \\
\hline Segurança no uso & $\mathrm{A}$ & $\mathrm{NA}$ & $\mathrm{NSA}$ & $\mathrm{NV}$ \\
\hline Obrigatórios & 37 & 01 & 76 & 0 \\
\hline Vida útil, Durabilidade e & $(32 \%)$ & $(1 \%)$ & $(67 \%)$ & NV \\
Desempenho Estrutural & $\mathrm{A}$ & $\mathrm{NA}$ & $\mathrm{NSA}$ & 27 \\
\hline Obrigatório & $231(83 \%)$ & $\begin{array}{c}28 \\
(10 \%)\end{array}$ & $\begin{array}{c}18 \\
(6 \%)\end{array}$ \\
\hline
\end{tabular}

A frequência de "NSA" (não se aplica) evidencia a necessidade de adequar as fichas de verificação ao caso estudado, considerando as características do empreendimento, assim como as características do sistema construtivo empregado.

Em geral, ao se desconsiderar a frequência de NSA, é possível verificar que o nível de atendimento é alto.

\section{Resultados da Aplicação das Fichas de Avaliação da Manutenção}

Diferentes das Fichas de Verificação da Obra, as Fichas de Avaliação da Manutenção das áreas internas da unidade habitacional abordam subsistemas e componentes específicos do edifício, abrangendo: Paredes/painéis de vedação; Estruturas; Pintura; Revestimento de piso; Revestimento de parede; Forro (pintura e estrutura); Esquadrias de madeira; Esquadrias (outros materiais possíveis); Vidraçaria; Instalaçôes elétricas; Instalações de telefonia, televisão e internet; Instalaçóes hidrossanitárias; e Instalaçōes de gás. 
A Ficha de Avaliação da Manutenção das áreas externas da unidade habitacional, por sua vez, se destina principalmente a situação de edificaçóes multifamiliares e seguem o mesmo princípio de organização das fichas para áreas internas, considerando aspectos físicos, como Cobertura; Pavimentação (calçadas e acessos internos ao lote); Fachadas; Instalaçóes de gás; Diversos: caixa d'água, caixa de gordura, para-raios e aterramentos SPDA.

A avaliação das dezenove unidades habitacionais envolveu uma análise mais aprofundada das unidades que apresentaram a incidência de não atendimento aos requisitos superior a $16 \%$ do total, uma situação que ocorreu ao menos em três das unidades habitacionais. Assim, nos casos de não atendimento, os itens verificados também foram classificados segundo o risco que isso apresentaria à edificação.

As condiçóes para determinar se o risco é Mínimo, Regular e Crítico são listadas a seguir:

- Mínimo: impacto recuperável. Anomalias endógenas ou falhas de manutençáo encontradas são causadas por pequenas perdas de desempenho e funcionalidade, sem a probabilidade de ocorrência de riscos relativos a impactos irrecuperáveis e parcialmente recuperáveis, afetando principalmente a estética ou atividades programáveis e planejadas (IBAPE, 2009).

- Regular: impacto parcialmente recuperável. Anomalias endógenas e falhas de manutenção encontradas provocam perda parcial de desempenho e funcionalidade da edificação sem prejuízo à operação direta de sistemas (IBAPE, 2009). Intervençóes para recuperação de desempenho são possíveis;

- Crítico: impacto irrecuperável. As anomalias endógenas efalhas de manutenção encontradas são irrecuperáveis no que diz respeito ao desempenho do sistema construtivo ou das instalaçôes ou da estrutura da edificação, comprometendo segurança, causando possíveis paralisaçóes e comprometimento sensível da vida útil (Adaptado de IBAPE, 2009);

Além disso, a parte final de todas as fichas apresenta um campo de preenchimento referente ao estado geral de manutenção, que pode ser classificado como ótimo, normal, deficiente, inexistente, não se aplica ou não verificado, segundo as definições a seguir:

- Ótimo: manutenção executada segundo as instruçôes de manuais e planos de manutenção, mantendo o desempenho e contendo espaço seguro para melhorias, modificações e ampliações; 
- Normal: manutenção executada segundo instruções de manuais e planos de manutenção de forma eficiente, mantendo o desempenho;

- Deficiente: manutenção executada parcialmente segundo instruçôes de manuais e planos de manutençáo, podendo haver queda no desempenho;

- Inexistente: manutenção não realizada.

- Náo se aplica/náo verificado: quando o indicador objeto da questáo inexiste na unidade ou edifício avaliado, ou quando não foram aplicados os métodos necessários para verificação do indicador objeto da questão.

\subsection{Verificação de Áreas Internas}

A Verificação das áreas internas da edificação inicia-se pelas condições das paredes e painéis de vedação, estruturas, revestimentos, forro, esquadrias e instalaçôes.

Nas paredes e painéis de vedaçáo, foi verificada a existência de fissuras, deformações, sinais de infiltração e ortogonalidade. As fissuras existentes nas unidades eram menores ou iguais aos valores estipulados como aceitáveis em $89 \%$ dos casos. As paredes não apresentam deformaçóes ou desaprumos (Tabela 13), porém observou-se uma frequência significativa de paredes com sinais de infiltraçóes e manchas (26\%), como exemplificado nas Figuras 2 e 3.

Tabela 13. Avaliação de paredes e painéis de vedação.

\begin{tabular}{lcccc}
\hline \multicolumn{1}{c}{ Paredes/Painéis de Vedação } & A & NA & NSA & NV \\
\hline $\begin{array}{l}\text { As fissuras existentes são menores ou iguais aos } \\
\text { valores estipulados }(\mathrm{n}=19)\end{array}$ & $\begin{array}{c}17 \\
(89 \%)\end{array}$ & $\begin{array}{c}2 \\
(11 \%)\end{array}$ & 0 & 0 \\
\hline Paredes sem deformações e desaprumos $(\mathrm{n}=19)$ & $\begin{array}{c}19 \\
(100 \%)\end{array}$ & 0 & 0 & 0 \\
\hline Paredes sem sinais de infiltração e manchas $(\mathrm{n}=19)$ & $\begin{array}{c}14 \\
(74 \%)\end{array}$ & $\begin{array}{c}5 \\
(26 \%)\end{array}$ & 0 & 0 \\
\hline Ortogonalidade de cantos $(\mathrm{n}=17)$ & $\begin{array}{c}17 \\
(100 \%)\end{array}$ & 0 & 0 & 0 \\
\hline
\end{tabular}


Avaliação de Desempenho em Uso e Manutenção de Habitações... Cap. 9

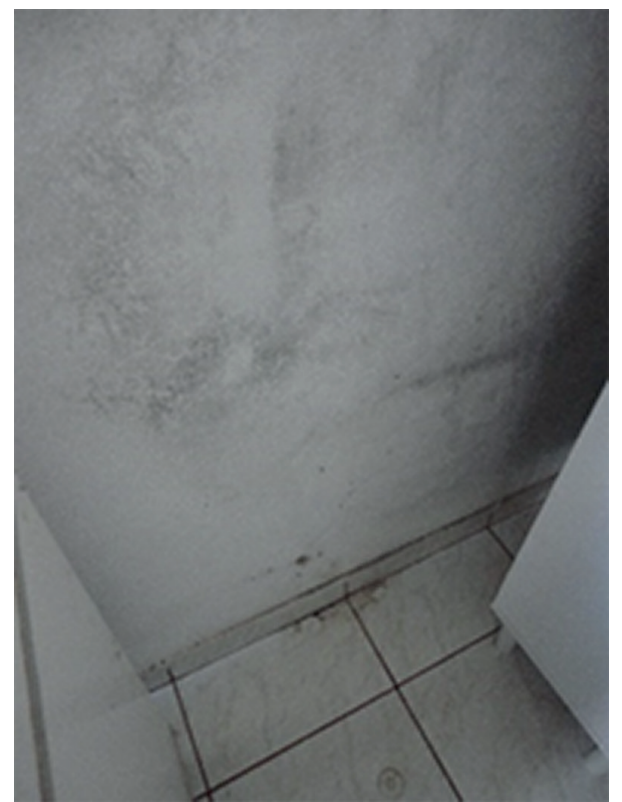

Figura 2. Exemplo de sinais de manchas em cozinha, grau de risco regular.

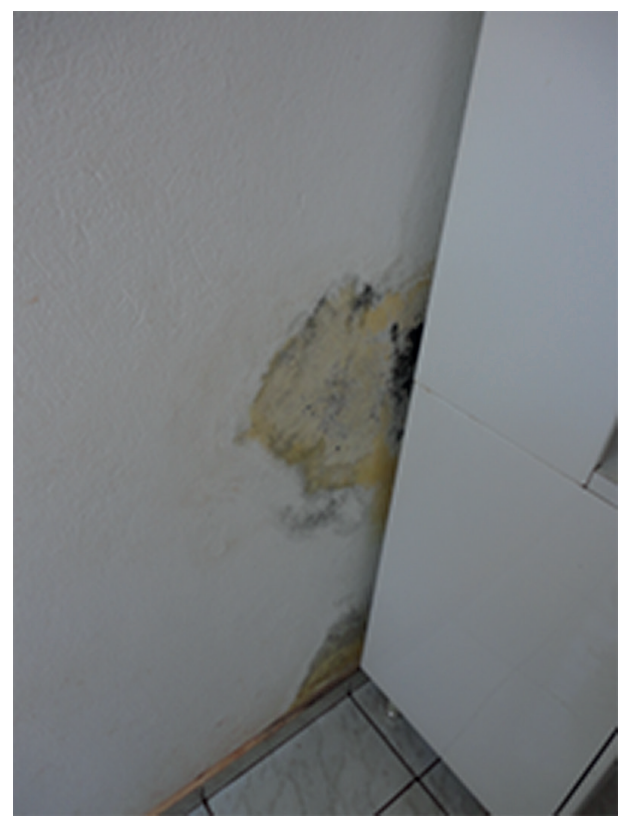

Figura 3. Exemplo de sinais de infiltração em cozinha, grau de risco crítico. 
As paredes e painéis de vedação apresentaram um estado de conservaçáo Normal em 84\% dos casos ou Deficiente em 16\%. Sinais de infiltrações ou manchas nas paredes das cozinhas, semelhantes aos apresentados nas figuras acima, foram detectados em cinco casos (26\%) e receberam uma classificação de grau de risco regular e crítico. No caso da Figura 3, a avaria foi claramente causada por vazamento na tubulaçáo de abastecimento de água do tanque.

A verificação das estruturas ocorre por meio da observação de fissuras, manchas de corrosão, deformaçóes, descolamentos do recobrimento, exposição de armaduras, infiltraçôes e eflorescências (Tabela 14). Fora os sinais de infiltração, com incidência de $11 \%$, os demais itens foram completamente atendidos.

Cabe destacar que, no caso apresentado, a estrutura e a vedação vertical compóem um único sistema, pois as paredes são estruturais. Tal particularidade aponta a necessidade de flexibilização dessa parte do instrumento para adequá-lo às características particulares dos sistemas e, assim, melhorar o desempenho das atividades de campo e da análise dos dados coletados.

Tabela 14. Avaliação de estruturas.

\begin{tabular}{|c|c|c|c|c|}
\hline Estruturas & A & NA & NSA & NV \\
\hline $\begin{array}{l}\text { As fissuras são menores ou iguais aos valores máximos } \\
\text { estipulados }(n=19)\end{array}$ & $\begin{array}{c}19 \\
(100 \%)\end{array}$ & 0 & 0 & 0 \\
\hline Não há manchas de corrosão e oxidação $(n=19)$ & $\begin{array}{c}19 \\
(100 \%)\end{array}$ & 0 & 0 & 0 \\
\hline Não há deformações ( $n=19$ ) & $\begin{array}{c}19 \\
(100 \%)\end{array}$ & 0 & 0 & 0 \\
\hline Não há descolamentos do recobrimento $(n=19)$ & $\begin{array}{c}19 \\
(100 \%)\end{array}$ & 0 & 0 & 0 \\
\hline Não há armaduras expostas $(n=19)$ & $\begin{array}{c}19 \\
(100 \%)\end{array}$ & 0 & 0 & 0 \\
\hline Não há sinais de infiltração e manchas ( $\mathrm{n}=19)$ & $\begin{array}{c}17 \\
(89 \%)\end{array}$ & $\begin{array}{c}2 \\
(11 \%)\end{array}$ & 0 & 0 \\
\hline Não há eflorescências ( $n=19$ ) & $\begin{array}{c}19 \\
(100 \%)\end{array}$ & 0 & 0 & 0 \\
\hline
\end{tabular}

O estado de conservação da estrutura foi avaliado como Ótimo (5\%), Normal (90\%) e Deficiente (5\%), sendo os casos deficientes relacionados aos sinais de infiltração e manchas. 
No caso da pintura, verificou-se a presença de fungos ou mofo, fissuras, bolhas, desgastes, descascamentos e sinais de infiltração. Constatouse um alto grau de atendimentos relacionados a náo presença de fissuras e de bolha (100\%) e ao não descascamento (84\%) (Tabela 15). Já os itens que apresentaram problemas consideráveis (não atendimento acima dos $17 \%)$ relacionam-se à presença de fungos ou mofo oriundos de umidade, observados em $21 \%$ dos casos com grau de risco mínimo, desgastes (37\% e grau de risco mínimo) e dos sinais de infiltração ( $21 \%$ e grau de risco regular).

Tabela 15. Avaliação de pinturas.

\begin{tabular}{lccrr}
\hline \multicolumn{1}{c}{ Pintura } & A & NA & NSA & NV \\
\hline $\begin{array}{l}\text { Não há presença de fungos ou mofo oriundos de umidade } \\
\text { excessiva ou infiltrações }(\mathrm{n}=19)\end{array}$ & $\begin{array}{c}15 \\
(79 \%)\end{array}$ & $\begin{array}{c}4 \\
(21 \%)\end{array}$ & 0 & 0 \\
\hline Não há fissuras $(\mathrm{n}=18)$ & $\begin{array}{c}18 \\
(100 \%)\end{array}$ & 0 & 0 & 0 \\
\hline Não há bolhas $(\mathrm{n}=18)$ & $\begin{array}{c}18 \\
(100 \%)\end{array}$ & 0 & 0 & 0 \\
\hline Não há desgastes $(\mathrm{n}=19)$ & $\begin{array}{c}12 \\
(63 \%)\end{array}$ & $\begin{array}{c}7 \\
(37 \%)\end{array}$ & 0 & 0 \\
\hline Não há descascamento $(\mathrm{n}=19)$ & $\begin{array}{c}16 \\
(84 \%)\end{array}$ & $\begin{array}{c}3 \\
(16 \%)\end{array}$ & 0 & 0 \\
\hline Não há sinais de infiltração ou manchas $(\mathrm{n}=19)$ & $\begin{array}{c}15 \\
(79 \%)\end{array}$ & $\begin{array}{c}(21 \%) \\
(21 \%)\end{array}$ & 0 & 0 \\
\hline
\end{tabular}

O estado de conservação da pintura foi avaliado como Normal (58\%) e Deficiente (42\%), sendo os casos mais significativos, aqueles relativos a desgastes na pintura e sinais de infiltração em sala, cozinha e dormitório.

Os revestimentos de piso (Tabela 16) não apresentaram mofo oriundo de infiltraçôes em $95 \%$ dos casos, não se observou caso de fissuras nem descascamento em 100\% dos casos e a ausência de descolamentos chegou a $94 \%$ dos casos. Os resultados não satisfatórios, ilustrado pelas Figuras 4 e 5 , referem-se à presença de desgastes (37\%) e sinais de infiltração (58\%). 
Tabela 16. Avaliação de revestimentos de piso.

\begin{tabular}{lllll}
\hline \multicolumn{1}{c}{ Revestimentos de Piso } & \multicolumn{1}{c}{ A } & NA & NSA & NV \\
\hline $\begin{array}{l}\text { Não há presença de fungos ou mofo oriundos de } \\
\text { umidade excessiva ou infiltrações }(\mathrm{n}=19)\end{array}$ & $\begin{array}{l}18 \\
(95 \%)\end{array}$ & $\begin{array}{l}1 \\
(5 \%)\end{array}$ & 0 & 0 \\
\hline Não há fissuras $(\mathrm{n}=19)$ & $\begin{array}{l}19 \\
(100 \%)\end{array}$ & 0 & 0 & 0 \\
\hline Não há desgastes $(\mathrm{n}=19)$ & $\begin{array}{l}12 \\
(63 \%)\end{array}$ & $\begin{array}{l}7 \\
(37 \%)\end{array}$ & 0 & 0 \\
\hline Não há descascamento $(\mathrm{n}=19)$ & $\begin{array}{l}19 \\
(100 \%)\end{array}$ & 0 & 0 & 0 \\
\hline Não há descolamentos ou desplacamentos $(\mathrm{n}=17)$ & $\begin{array}{l}16 \\
(94 \%)\end{array}$ & $\begin{array}{l}1 \\
(6 \%)\end{array}$ & 0 & 0 \\
\hline Não há sinais de infiltração ou manchas $(\mathrm{n}=19)$ & $\begin{array}{l}8 \\
(42 \%)\end{array}$ & $\begin{array}{l}11 \\
(58 \%)\end{array}$ & 0 & 0 \\
\hline
\end{tabular}

Os casos de desgaste são frequentes no banheiro, principalmente no box, e na cozinha, sobretudo nos locais de maior fluxo como as portas e na área da pia, apresentando graus de risco mínimo e regular. Os sinais de infiltração ou manchas no piso ocorreram no banheiro, identificados como risco mínimo e regular, e na cozinha, com risco mínimo.

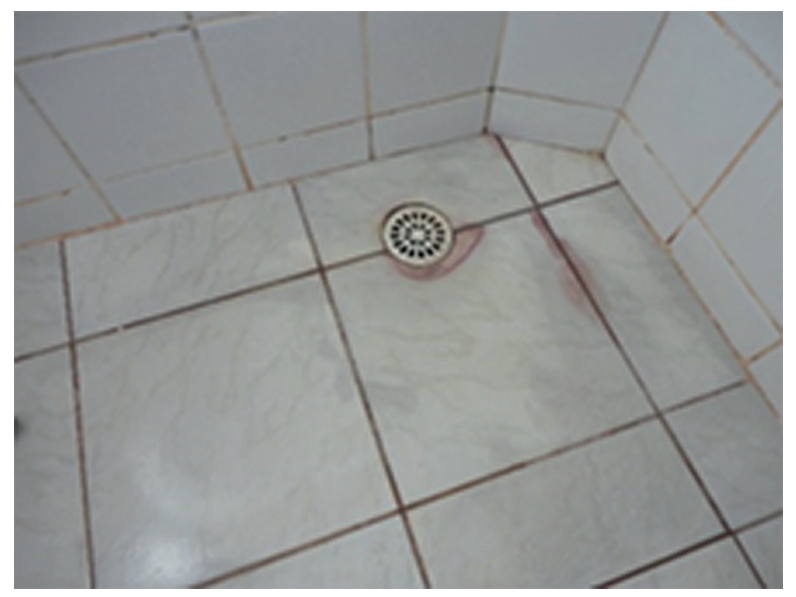

Figura 4. Exemplo de sinais de infiltração e manchas no piso de banheiro, grau de risco mínimo. 


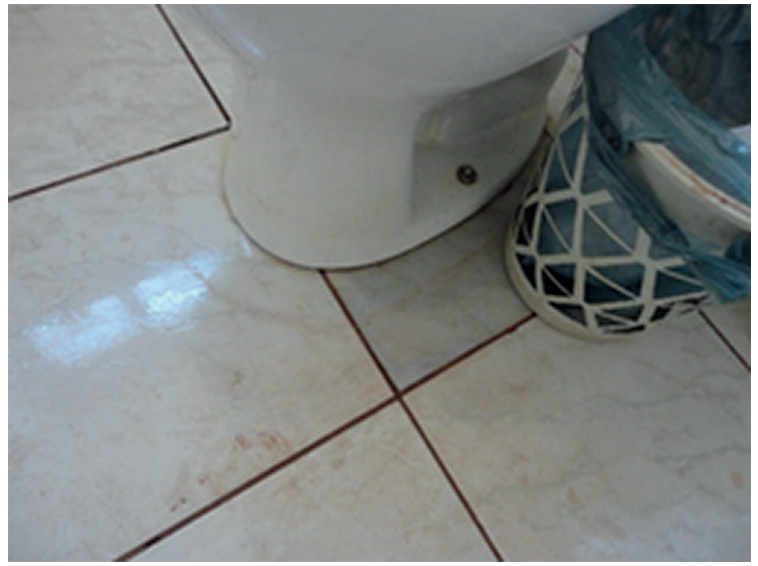

Figura 5. Exemplo de sinais de infiltração e manchas no piso do banheiro, grau de risco regular.

O estado de conservaçáo do revestimento de piso foi considerado Ótimo (5\%), Normal (63\%) e Deficiente (32\%), uma vez que que estes se relacionam com maior frequência aos sinais de infiltração ou manchas no piso da cozinha, com grau de risco mínimo, e de banheiros (box), com grau de risco mínimo e regular.

A inspeção dos revestimentos de parede verificou que não havia presença de mofo oriundo de infiltraçóes, fissuras, desgastes e descascamento, nem descolamentos em, no mínimo, 89\% dos casos. Já os sinais de infiltração ou mancha foram encontrados em 32\% dos casos (Tabela 17), sendo os mais frequentes identificados nos banheiros, sobretudo na área do box, abaixo de 1,50 $\mathrm{m}$ de altura (grau de risco mínimo e regular).

Tabela 17. Avaliação de revestimentos de parede.

\begin{tabular}{lcccc}
\hline \multicolumn{1}{c}{ Revestimentos de Parede } & A & NA & NSA & NV \\
\hline $\begin{array}{l}\text { Não há presença de fungos ou mofo oriundos de } \\
\text { umidade excessiva ou infiltrações }(\mathrm{n}=19)\end{array}$ & $\begin{array}{c}18 \\
(95 \%)\end{array}$ & $\begin{array}{c}1 \\
(5 \%)\end{array}$ & 0 & 0 \\
\hline Não há fissuras $(\mathrm{n}=19)$ & $\begin{array}{c}18 \\
(95 \%)\end{array}$ & $\begin{array}{c}1 \\
(5 \%)\end{array}$ & 0 & 0 \\
\hline Não há desgastes $(\mathrm{n}=19)$ & $\begin{array}{c}18 \\
(95 \%)\end{array}$ & $\begin{array}{c}1 \\
(5 \%)\end{array}$ & 0 & 0 \\
\hline Não há descascamento $(\mathrm{n}=19)$ & $\begin{array}{c}17 \\
(95 \%)\end{array}$ & $\begin{array}{c}2 \\
(5 \%)\end{array}$ & 0 & 0 \\
\hline Não há descolamentos ou desplacamentos $(\mathrm{n}=19)$ & $\begin{array}{c}13 \\
(89 \%)\end{array}$ & $\begin{array}{c}6 \\
(11 \%)\end{array}$ & 0 & 0 \\
\hline
\end{tabular}


O estado de conservaçáo do revestimento das paredes foi avaliado como Normal em 74\% dos casos e Deficiente em 26\% dos casos.

$\mathrm{Na}$ verificação dos itens do forro (pintura e estrutura), verificou-se a presença de fissuras, fungos ou mofo, deformaçóes, sinais de infiltração ou manchas, bolhas, descascamento ou partes faltantes. Os resultados relacionados ao forro (pintura e estrutura) são 100\% satisfatórios em relação às fissuras (Tabela 18), à presença de mofo oriundo de infiltrações, às partes faltantes, a bolhas e descascamentos. Não há presença de deformações em $95 \%$ dos casos.

Tabela 18. Avaliação de forros.

\begin{tabular}{|c|c|c|c|c|}
\hline Forro (pintura e estrutura) & A & NA & NSA & NV \\
\hline $\begin{array}{l}\text { As fissuras são menores ou iguais aos } \\
\text { valores máximos estipulados }(n=19)\end{array}$ & $19(100 \%)$ & 0 & 0 & 0 \\
\hline $\begin{array}{l}\text { Não há presença de fungos ou mofo } \\
\text { oriundos de umidade excessiva ou } \\
\text { infiltrações }(n=19)\end{array}$ & $19(100 \%)$ & 0 & 0 & 0 \\
\hline Não há deformações no forro $(n=19)$ & $\begin{array}{c}18 \\
(95 \%)\end{array}$ & $\begin{array}{c}1 \\
(5 \%)\end{array}$ & 0 & 0 \\
\hline $\begin{array}{l}\text { Não há sinais de infiltração ou manchas de } \\
\text { umidade no forro }(n=19)\end{array}$ & $\begin{array}{c}14 \\
(74 \%)\end{array}$ & $\begin{array}{c}5 \\
(26 \%)\end{array}$ & 0 & 0 \\
\hline Não faltam partes do forro $(n=19)$ & $19(100 \%)$ & 0 & 0 & 0 \\
\hline Não há bolhas no forro $(n=19)$ & $19(100 \%)$ & 0 & 0 & 0 \\
\hline Não há descascamento no forro $(n=19)$ & $19(100 \%)$ & 0 & 0 & 0 \\
\hline
\end{tabular}

O estado de conservação do forro (pintura e estrutura) foi considerado como Ótimo (11\%) e Normal (89\%). Não há situações deficientes. Existem sinais de infiltração ou manchas no forro da sala e dormitório com grau de risco mínimo.

Nos itens relacionados às esquadrias de madeira, verificouse a presença de apodrecimento, descolamento, empenamentos, mau funcionamento, desgastes excessivos, sinais de infiltração, facilidade de acesso para limpeza, caimento de peitoril, pingadeira e calafetação. As esquadrias em madeira estão presentes apenas nas portas internas.

As esquadrias estão funcionando (89\%), não faltam partes ou peças (95\%) e há facilidade de acesso, com segurança para manutenção e limpeza (89\%). No entanto, há desgaste excessivo (16\%) das esquadrias (Tabela 19). 
Tabela 19. Avaliação de esquadrias de madeira.

\begin{tabular}{|c|c|c|c|c|}
\hline Esquadrias de Madeira & A & NA & NSA & NV \\
\hline Não há apodrecimento das esquadrias ( $\mathrm{n}=19$ ) & $\begin{array}{c}19 \\
(100 \%)\end{array}$ & 0 & 0 & 0 \\
\hline Não há descolamento das esquadrias ( $n=19)$ & $\begin{array}{c}19 \\
(100 \%)\end{array}$ & 0 & 0 & 0 \\
\hline Não há empenamentos das esquadrias $(n=19)$ & $\begin{array}{c}19 \\
(100 \%)\end{array}$ & 0 & 0 & 0 \\
\hline Esquadrias funcionando corretamente $(\mathrm{n}=19)$ & $\begin{array}{c}17 \\
(89 \%)\end{array}$ & $\begin{array}{c}2 \\
(11 \%)\end{array}$ & 0 & 0 \\
\hline Não faltam partes ou peças das esquadrias $(n=19)$ & $\begin{array}{c}18 \\
(95 \%)\end{array}$ & $\begin{array}{c}1 \\
(5 \%)\end{array}$ & 0 & 0 \\
\hline Não há desgastes excessivos nas esquadrias $(n=19)$ & $\begin{array}{c}16 \\
(84 \%)\end{array}$ & $\begin{array}{c}3 \\
(16 \%)\end{array}$ & 0 & 0 \\
\hline $\begin{array}{l}\text { Não há sinais de infiltração e manchas nas } \\
\text { esquadrias }(n=19)\end{array}$ & $\begin{array}{c}19 \\
(100 \%)\end{array}$ & 0 & 0 & 0 \\
\hline $\begin{array}{l}\text { Há facilidade de acesso com segurança para } \\
\text { manutenção e limpeza }(n=19)\end{array}$ & $\begin{array}{c}17 \\
(89 \%) \\
\end{array}$ & $\begin{array}{c}2 \\
(11 \%) \\
\end{array}$ & 0 & 0 \\
\hline $\begin{array}{l}\text { O peitoril apresenta caimento para o lado externo de } \\
\text { ambiente }(n=19)\end{array}$ & 0 & 0 & $\begin{array}{c}19 \\
(100 \%)\end{array}$ & 0 \\
\hline Existe pingadeira $(n=19)$ & 0 & 0 & $\begin{array}{c}19 \\
(100 \%)\end{array}$ & 0 \\
\hline $\begin{array}{l}\text { Calafetação: verificar a interface esquadria - vão } \\
(n=12)\end{array}$ & $\begin{array}{c}12 \\
(100 \%)\end{array}$ & 0 & 0 & 7 \\
\hline
\end{tabular}

A avaliação do estado de conservação referente às esquadrias de madeira foi considerada Normal (84\%) e Deficiente (16\%). Os casos deficientes são decorrentes de desgaste excessivo nas esquadrias de madeira do banheiro e dormitório, com grau de risco regular.

Os itens verificados relacionados às esquadrias de alumínio dizem respeito à corrosão, deformações, desgastes, mau funcionamento, sinais de infiltração, partes faltantes, facilidade de acesso, caimento do peitoril, pingadeira e calafetação. As esquadrias de alumínio estão presentes nas portas externas (sala e cozinha) e nas janelas das unidades habitacionais. As esquadrias de alumínio tiveram os itens "caimento do peitoril" e "pingadeira" atendidos em 100\% dos casos (Tabela 20). Os demais itens atendidos foram: não há corrosão (89\%), não faltam parte ou peças (95\%), não há sinais de infiltração $(89 \%)$ e há facilidade de acesso com segurança para manutenção e limpeza (84\%). 
Os itens náo atendidos são em relaçáo a deformações (47\%), desgastes excessivos (32\%), funcionamento correto das esquadrias (53\%), e calafetação $(33 \%)$.

Tabela 20. Avaliação de esquadrias de alumínio.

\begin{tabular}{|c|c|c|c|c|}
\hline Esquadrias de alumínio & A & NA & NSA & NV \\
\hline Não há corrosão nas esquadrias ( $\mathrm{n}=19)$ & $\begin{array}{c}17 \\
(89 \%)\end{array}$ & $\begin{array}{c}2 \\
(11 \%)\end{array}$ & 0 & 0 \\
\hline Não há deformações nas esquadrias ( $n=19$ ) & $\begin{array}{c}10 \\
(53 \%)\end{array}$ & $\begin{array}{c}9 \\
(47 \%)\end{array}$ & 0 & 0 \\
\hline Não há desgastes excessivos nas esquadrias $(n=19)$ & $\begin{array}{c}13 \\
(68 \%)\end{array}$ & $\begin{array}{c}6 \\
(32 \%)\end{array}$ & 0 & 0 \\
\hline Esquadrias funcionando corretamente $(n=19)$ & $\begin{array}{c}9 \\
(47 \%)\end{array}$ & $\begin{array}{c}10 \\
(53 \%)\end{array}$ & 0 & 0 \\
\hline Não faltam partes ou peças das esquadrias $(n=19)$ & $\begin{array}{c}18 \\
(95 \%)\end{array}$ & $\begin{array}{c}1 \\
(5 \%)\end{array}$ & 0 & 0 \\
\hline Não há sinais de infiltração e manchas $(n=19)$ & $\begin{array}{c}17 \\
(89 \%)\end{array}$ & $\begin{array}{c}2 \\
(11 \%)\end{array}$ & 0 & 0 \\
\hline $\begin{array}{l}\text { Há facilidade de acesso com segurança para } \\
\text { manutenção e limpeza }(n=19)\end{array}$ & $\begin{array}{c}16 \\
(84 \%)\end{array}$ & $\begin{array}{c}3 \\
(16 \%)\end{array}$ & 0 & 0 \\
\hline $\begin{array}{l}\text { O peitoril apresenta caimento para o lado externo do } \\
\text { ambiente }(n=19)\end{array}$ & $\begin{array}{c}19 \\
(100 \%)\end{array}$ & 0 & 0 & 0 \\
\hline Existe pingadeira $(n=19)$ & $\begin{array}{c}19 \\
(100 \%)\end{array}$ & 0 & 0 & 0 \\
\hline Calafetação: verificar a interface esquadria-vão $(n=16)$ & $\begin{array}{c}10 \\
(63 \%) \\
\end{array}$ & $\begin{array}{c}5 \\
(33 \%) \\
\end{array}$ & $\begin{array}{c}1 \\
(1 \%) \\
\end{array}$ & 3 \\
\hline
\end{tabular}

Os casos com deformaçóes nas esquadrias estão presentes nas janelas da sala e cozinha (grau de risco mínimo e regular), janela de dormitório (grau de risco regular e crítico) e em portas da sala e cozinha (grau de risco regular). Os desgastes excessivos nas esquadrias de alumínio estáo presentes no dormitório (grau de risco regular e crítico). Os casos de funcionamento incorreto foram identificados em cozinha (grau de risco mínimo e regular), sala (grau de risco mínimo e crítico) e dormitório (regular e crítico) (Figura 6). Os casos de calafetação (interface janela e vão) que não atendem às exigências foram encontrados em cozinhas (grau de risco mínimo) e dormitórios (grau de risco mínimo e regular). 

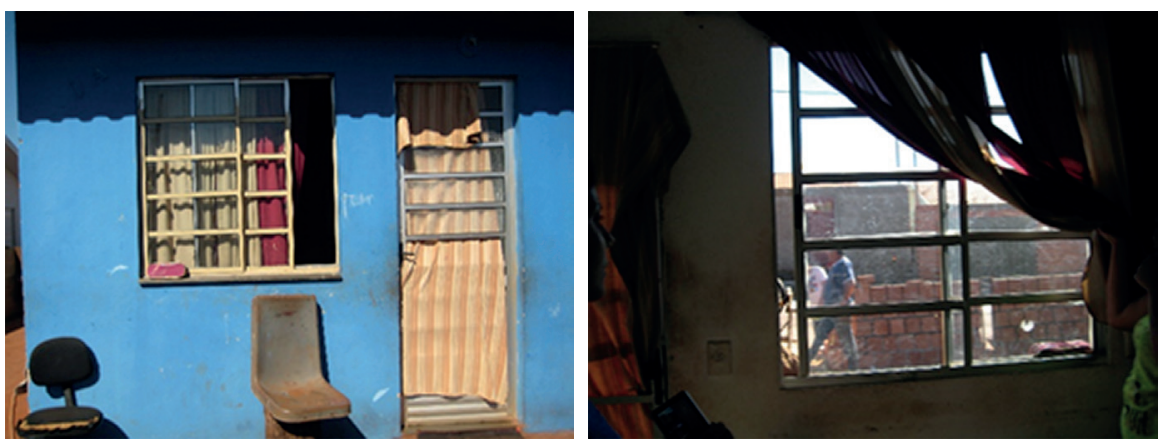

Figura 6. Deformações nas esquadrias de alumínio de salas de estar que dificultam sua plena abertura, Grau de risco crítico.

A conservação das esquadrias de alumínio foi avaliada como: Ótimo (5\%), Normal (42\%) e Deficiente (53\%). Os casos deficientes estão relacionados às deformaçôes, desgastes e ao mau funcionamento das esquadrias de alumínio.

$\mathrm{Na}$ vidraçaria, foram observadas a presença de trincas, partes soltas ou faltantes e facilidade de acesso para limpeza. Na verificação dos vidros, foram atendidos os seguintes itens: não há trincas (84\%) e facilidade de acesso com segurança $(100 \%)$, Tabela 21 . Os itens não atendidos foram: partes soltas (26\%) e partes faltantes (28\%).

Tabela 21. Avaliação da vidraçaria.

\begin{tabular}{lcccc}
\hline \multicolumn{1}{c}{ Vidraçaria } & A & NA & NSA & NV \\
\hline Não há trincas $(\mathrm{n}=19)$ & $\begin{array}{c}16 \\
(84 \%)\end{array}$ & $\begin{array}{c}3 \\
(16 \%)\end{array}$ & 0 & 0 \\
\hline Não há partes soltas $(\mathrm{n}=19)$ & $\begin{array}{c}14 \\
(74 \%)\end{array}$ & $\begin{array}{c}5 \\
(26 \%)\end{array}$ & 0 & 0 \\
\hline Não há partes faltantes ou quebradas $(\mathrm{n}=18)$ & $\begin{array}{c}13 \\
(2 \%)\end{array}$ & $\begin{array}{c}5 \\
(28 \%)\end{array}$ & 0 & 1 \\
\hline $\begin{array}{l}\text { Há facilidade de acesso com segurança para } \\
\text { manutenção e limpeza }(\mathrm{n}=18)\end{array}$ & $\begin{array}{c}18 \\
(100 \%)\end{array}$ & 0 & 0 & 1 \\
\hline
\end{tabular}

As partes faltantes ou quebradas em vidraçaria foram verificadas na cozinha (grau de risco regular), sala (grau de risco regular), banheiro (grau de risco crítico) e dormitório (grau de risco crítico). 
A conservação dos vidros foi avaliada como Ótima (5\%), Normal (63\%) e Deficiente (32\%). Os itens deficientes estão relacionados à presença de trincas, partes soltas e faltantes.

As instalaçóes elétricas foram inspecionadas em relação à presença de peças defeituosas, quadro de distribuição, dispositivos de acionamento, uso de benjamins, fiação aparente e facilidade de acesso para limpeza. Os itens das instalaçôes elétricas que atenderam à inspeção (Tabela 22) foram: não há sinais de infiltração (100\%), quadro de distribuição possui disjuntores (95\%), dispositivo de acionamento está funcionando (92\%), facilidade de acesso com segurança para manutenção e limpeza (95\%) e há identificação do quadro de distribuição (89\%).

Tabela 22. Avaliação de instalações elétricas.

\begin{tabular}{|c|c|c|c|c|}
\hline Instalações Elétricas & A & NA & NSA & NV \\
\hline Não há peças defeituosas $(n=19)$ & $\begin{array}{c}15 \\
(79 \%) \\
\end{array}$ & $\begin{array}{c}4 \\
(21 \%) \\
\end{array}$ & 0 & 0 \\
\hline Quadro de distribuição com todos os disjuntores $(n=19)$ & $\begin{array}{c}18 \\
(95 \%)\end{array}$ & $\begin{array}{c}1 \\
(5 \%) \\
\end{array}$ & 0 & 0 \\
\hline Dispositivos de acionamento estão funcionando $(n=13)$ & $\begin{array}{c}12 \\
(92 \%)\end{array}$ & $\begin{array}{c}1 \\
(8 \%)\end{array}$ & 0 & 6 \\
\hline Não há tomadas de piso sem tampa $(\mathrm{n}=0)$ & 0 & 0 & $\begin{array}{c}19 \\
(100 \%)\end{array}$ & 0 \\
\hline Não há uso de benjamins e réguas $(n=19)$ & $\begin{array}{c}3 \\
(16 \%)\end{array}$ & $\begin{array}{c}16 \\
(84 \%)\end{array}$ & 0 & 0 \\
\hline Não há fiação aparente $(n=19)$ & $\begin{array}{c}13 \\
(68 \%)\end{array}$ & $\begin{array}{c}6 \\
(32 \%)\end{array}$ & 0 & 0 \\
\hline Não há sinais de infiltração $(n=19)$ & $\begin{array}{c}19 \\
(100 \%)\end{array}$ & 0 & 0 & 0 \\
\hline $\begin{array}{l}\text { Há facilidade de acesso com segurança para manutenção } \\
\text { e limpeza e inspeção }(n=19)\end{array}$ & $\begin{array}{c}18 \\
(95 \%)\end{array}$ & $\begin{array}{c}1 \\
(5 \%)\end{array}$ & 0 & 0 \\
\hline O quadro de distribuição está identificado $(n=19)$ & $\begin{array}{c}17 \\
(89 \%)\end{array}$ & $\begin{array}{c}2 \\
(11 \%)\end{array}$ & 0 & 0 \\
\hline
\end{tabular}

Os itens não atendidos foram: há peças e componentes defeituosos (21\%), há uso de benjamins e réguas $(84 \%)$ e há presença de fiação aparente (32\%). 
As instalações elétricas com peças defeituosas foram verificadas na sala (grau de risco mínimo e crítico), dormitório (grau de risco mínimo) e cozinha (grau de risco regular).
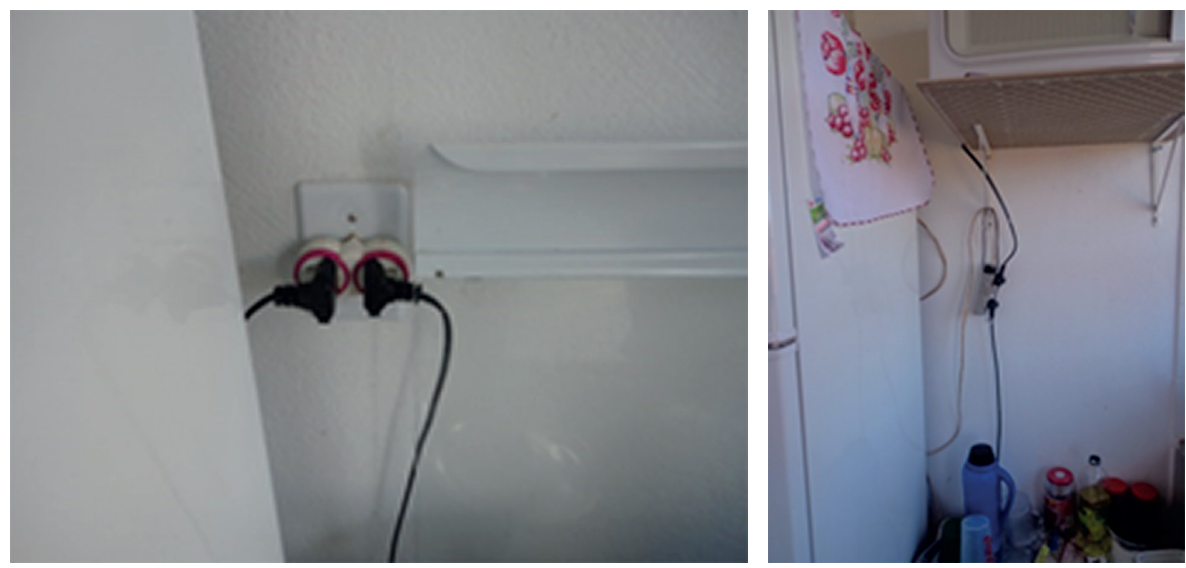

Figura 7. Exemplo de instalações elétricas - uso de benjamins e réguas em cozinhas, grau de risco mínimo.

O uso de benjamins e réguas foi encontrado na sala de estar (risco mínimo e crítico), no dormitório (grau de risco crítico) e na cozinha (grau de risco mínimo, regular e crítico), Figura 7. O estado de conservação das instalações elétricas foi avaliado como ótimo em $5 \%$ dos casos, Normal (58\% dos casos) e Deficiente (37\% dos casos).

As instalaçóes de telefonia, TV e internet foram avaliadas de acordo com a presença das peças defeituosas, aquecimento nas instalaçóes, funcionamento das instalações, presença de tomadas, fiação aparente, sinais de infiltração e facilidade de acesso para manutenção e limpeza. A maioria dos itens da avaliação das instalaçóes de telefonia, TV e internet atendem aos itens verificados (Tabela 23). As fiaçôes aparentes (74\% dos casos) são inevitáveis nesse caso, pois correspondem àquelas que conectam os equipamentos à rede e, nem sempre, são as energizadas. 
Tabela 23. Avaliação das instalações de telefonia, TV e internet.

\begin{tabular}{|c|c|c|c|c|}
\hline Instalações de Telefonia, TV e Internet & A & NA & NSA & NV \\
\hline Não há peças defeituosas $(n=18)$ & $\begin{array}{c}18 \\
(100 \%)\end{array}$ & 0 & 0 & 1 \\
\hline Não há aquecimento nas instalações ( $n=18$ ) & $\begin{array}{c}18 \\
(100 \%)\end{array}$ & 0 & 0 & 1 \\
\hline Instalações estão funcionando ( $\mathrm{n}=19$ ) & $\begin{array}{c}19 \\
(100 \%)\end{array}$ & 0 & 0 & 0 \\
\hline Não há tomadas de piso sem tampa $(\mathrm{n}=0)$ & 0 & 0 & $\begin{array}{c}19 \\
(100 \%)\end{array}$ & 0 \\
\hline Não há fiação aparente ( $\mathrm{n}=19)$ & $\begin{array}{c}14 \\
(74 \%)\end{array}$ & $\begin{array}{c}05 \\
(26 \%) \\
\end{array}$ & 0 & 0 \\
\hline Não há sinais de infiltração $(n=19)$ & $\begin{array}{c}19 \\
(100 \%)\end{array}$ & 0 & 0 & 0 \\
\hline $\begin{array}{l}\text { Há facilidade de acesso com segurança para a } \\
\text { manutenção e limpeza }(n=19)\end{array}$ & $\begin{array}{c}19 \\
(100 \%)\end{array}$ & 0 & 0 & 0 \\
\hline
\end{tabular}

O estado de conservação das instalaçóes telefônicas, de TV e internet foi avaliado em Ótimo (5\%), Normal (90\%) e Deficiente (5\%).

Detectou-se a execuçáo de furos em telhado para passagem de antenas, sem a devida instrução e procedimento de estanqueidade, permitindo eventuais infiltraçôes de águas de chuvas.

No projeto de instalaçôes elétricas, estão previstos pontos para telefone e para antena. Devido à dificuldade de passagem de cabeamento, intervençôes foram realizadas de modo inadequado, acarretando em quebra na estanqueidade da cobertura.

As instalaçóes hidrossanitárias foram verificadas em relação à presença de detritos nos ralos, vazamentos, descolamentos, rejuntamentos danificados, sinais de infiltração, inclinaçáo do piso, ruídos excessivos, facilidade de acesso e integridade das peças sanitárias. A maioria dos itens relacionados à inspeção das instalações hidrossanitárias atenderam aos requisitos que constam na ficha de avaliação (Tabela 24). Os itens que não atendem satisfatoriamente aos requisitos são: vazamentos nas instalaçóes (17\%) e situaçôes em que a água de banho e limpeza não corre para o ralo $(16 \%)$. 
Tabela 24. Avaliação das instalações hidrossanitárias.

\begin{tabular}{|c|c|c|c|c|}
\hline Instalações Hidrossanitárias & A & NA & NSA & NV \\
\hline Não há acúmulo de detritos nos ralos $(\mathrm{n}=18)$ & $\begin{array}{c}16 \\
(89 \%) \\
\end{array}$ & $\begin{array}{c}2 \\
(11 \%) \\
\end{array}$ & 0 & 1 \\
\hline Não há vazamentos nas instalações ( $\mathrm{n}=18$ ) & $\begin{array}{c}15 \\
(83 \%) \\
\end{array}$ & $\begin{array}{c}3 \\
(17 \%) \\
\end{array}$ & 0 & 1 \\
\hline Não há fissuras nas peças sanitárias ( $\mathrm{n}=19)$ & $\begin{array}{c}18 \\
(95 \%)\end{array}$ & $\begin{array}{c}1 \\
(5 \%)\end{array}$ & 0 & 0 \\
\hline Não há peças sanitárias com descolamentos ( $\mathrm{n}=19)$ & $\begin{array}{c}18 \\
(95 \%)\end{array}$ & $\begin{array}{c}1 \\
(5 \%)\end{array}$ & 0 & 0 \\
\hline Não há rejuntamento danificado nas instalações ( $\mathrm{n}=19)$ & $\begin{array}{c}17 \\
(89 \%)\end{array}$ & $\begin{array}{c}2 \\
(11 \%)\end{array}$ & 0 & 0 \\
\hline $\begin{array}{l}\text { Não há sinais de infiltração e manchas nas instalações } \\
(\mathrm{n}=19)\end{array}$ & $\begin{array}{c}17 \\
(89 \%)\end{array}$ & $\begin{array}{c}2 \\
(11 \%)\end{array}$ & 0 & 0 \\
\hline Água de banho e limpeza corre para o ralo $(n=19)$ & $\begin{array}{c}16 \\
(84 \%)\end{array}$ & $\begin{array}{c}3 \\
(16 \%)\end{array}$ & 0 & 0 \\
\hline $\begin{array}{l}\text { Não há ruídos excessivos no decorrer da utilização das } \\
\text { instalações }(n=19)\end{array}$ & $\begin{array}{c}19 \\
(100 \%)\end{array}$ & 0 & 0 & 0 \\
\hline $\begin{array}{l}\text { Há facilidade de acesso com segurança para manutenção e } \\
\text { limpeza }(n=18)\end{array}$ & $\begin{array}{c}18 \\
(100 \%)\end{array}$ & 0 & 0 & 1 \\
\hline $\begin{array}{l}\text { As peças de utilização e demais componentes dos sistemas } \\
\text { hidrossanitários que são manipulados pelos usuários não } \\
\text { possuem cantos e superfícies ásperas }(n=19)\end{array}$ & $\begin{array}{c}17 \\
(89 \%)\end{array}$ & $\begin{array}{c}2 \\
(11 \%)\end{array}$ & 0 & 0 \\
\hline
\end{tabular}

Foram observadas instalaçóes hidrossanitárias com vazamentos na cozinha (grau de risco mínimo e regular) e área de serviço (grau de risco crítico).

O estado de conservação das instalaçóes hidrossanitárias foi avaliado em Normal (79\%) e Deficiente (21\%).

Ao inspecionar as superfícies de peças, verificou-se que a bancada da pia de cozinha em granilite apresentava, em vários casos, excessivo desgaste e alta porosidade, com possibilidade de ruptura e impedimento da higienização adequada.

Nas instalaçóes de gás, foram inspecionadas e verificadas a presença do ambiente exclusivo e ventilado, a conexáo do registro e a pintura das tubulaçóes. Há uma instalação de gás (tubulação de interligação entre o botijão, no abrigo externo, e o fogáo, na cozinha, totalmente embutida). Foi verificado o armazenamento indevido do botijão de $13 \mathrm{~kg}$ no interior da edificação em 89\% dos casos (grau de risco crítico), Tabela 25 e Figura 8, além da instalação do botijão no exterior, porém fora do abrigo (Figura 9). 
Avaliação de Desempenho de Tecnologias Construtivas Inovadoras:

Conforto Ambiental, Durabilidade e Pós-Ocupação

Tabela 25. Avaliação da instalação de gás.

\begin{tabular}{lcccc}
\hline \multicolumn{1}{c}{ Instalações de Gás } & A & NA & NSA & NV \\
\hline $\begin{array}{l}\text { Armazenamento de gás está fora das } \\
\text { edificações, em ambiente exclusivo e com } \\
\text { ventilação }(n=19)\end{array}$ & $\begin{array}{c}2 \\
(11 \%)\end{array}$ & $\begin{array}{c}17 \\
(89 \%)\end{array}$ & 0 & 0 \\
\hline $\begin{array}{l}\text { O ponto de conexão do registro interno está em } \\
\text { local acessível }(n=19)\end{array}$ & $\begin{array}{c}19 \\
(100 \%)\end{array}$ & 0 & 0 & 0 \\
\hline $\begin{array}{l}\text { As tubulações estão pintadas sem qualquer } \\
\text { dano, inclusive com relação aos suportes } \\
\text { empregados }(n=19)\end{array}$ & 0 & 0 & $\begin{array}{c}19 \\
(100 \%)\end{array}$ & 0 \\
\hline
\end{tabular}

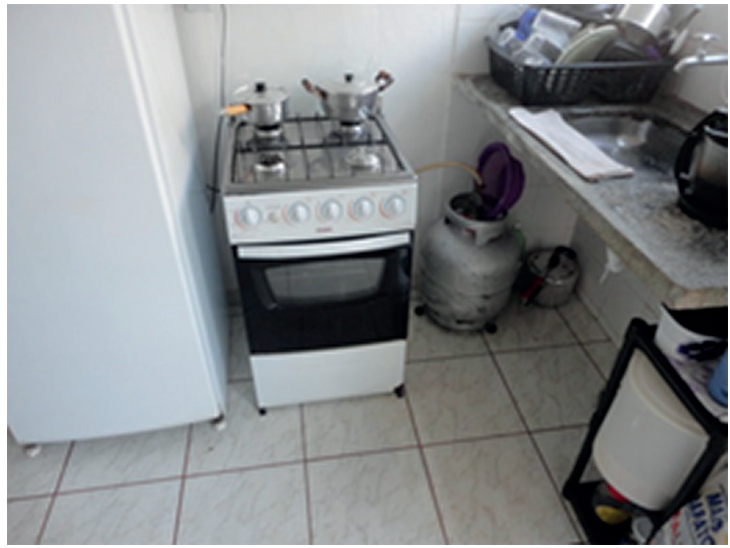

Figura 8. Instalações de gás - armazenamento de gás no interior da edificação, grau de risco crítico.

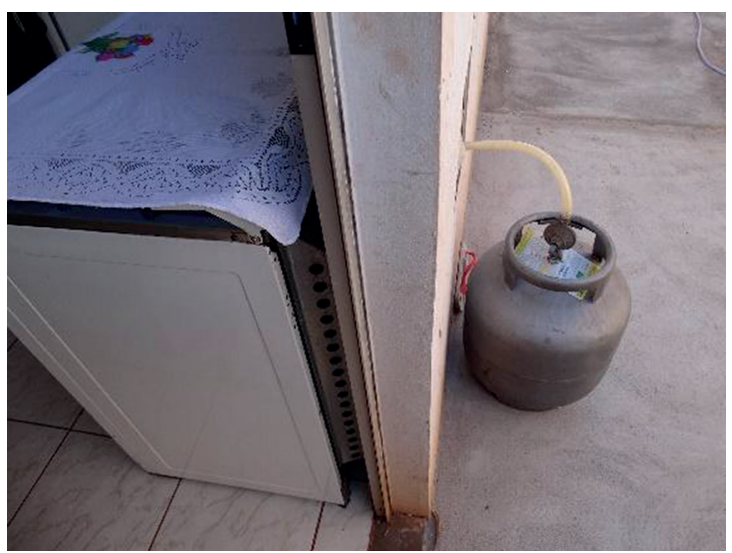

Figura 9. Instalações de gás com botiião fora do abrigo, grau de risco mínimo. 
O estado de conservação das instalações de gás foi avaliado como Normal (37\%) e Deficiente (63\%).

Os resultados da avaliação geral das áreas internas constam na Tabela 26. É possível verificar que, dentre os itens verificados, aqueles que atingiram falhas em frequência superior a 16\% estão: pintura, revestimento de piso, esquadrias de alumínio, vidraçaria, instalaçôes elétricas e instalaçôes de gás.

Tabela 26. Quadro geral de avaliação das áreas internas.

\begin{tabular}{lccccccc}
\hline \multicolumn{1}{c}{ Avaliação } & A & NA & NSA & A & NA & NSA & NV \\
\hline Paredes/painéis de vedação & 67 & 7 & 0 & $91 \%$ & $9 \%$ & $0 \%$ & 2 \\
\hline Estruturas & 131 & 2 & 0 & $99 \%$ & $1 \%$ & $0 \%$ & 0 \\
\hline Pintura & 94 & 18 & 0 & $84 \%$ & $16 \%$ & $0 \%$ & 2 \\
\hline Revestimentos de piso & 92 & 20 & 0 & $82 \%$ & $18 \%$ & $0 \%$ & 2 \\
\hline Revestimentos de parede & 102 & 12 & 0 & $89 \%$ & $11 \%$ & $0 \%$ & 0 \\
\hline Forro (pintura e estrutura) & 127 & 6 & 0 & $95 \%$ & $5 \%$ & $0 \%$ & 0 \\
\hline Esquadrias de madeira & 161 & 10 & 34 & $78 \%$ & $5 \%$ & $17 \%$ & 4 \\
\hline Esquadrias de alumínio & 148 & 38 & 1 & $79 \%$ & $20 \%$ & $1 \%$ & 3 \\
\hline Vidraçaria & 61 & 13 & 0 & $82 \%$ & $18 \%$ & $0 \%$ & 2 \\
\hline Instalações elétricas & 115 & 31 & 19 & $70 \%$ & $19 \%$ & $11 \%$ & 6 \\
\hline Instalações de telefonia, tv e internet & 107 & 5 & 19 & $82 \%$ & $4 \%$ & $14 \%$ & 2 \\
\hline Instalações hidrossanitárias & 171 & 16 & 0 & $91 \%$ & $9 \%$ & $0 \%$ & 3 \\
\hline Instalações de gás & 2 & 17 & 38 & $3 \%$ & $30 \%$ & $67 \%$ & 1 \\
\hline Totais & 1378 & 195 & 111 & $82 \%$ & $12 \%$ & $6 \%$ & 27 \\
\hline
\end{tabular}

A Tabela 19 apresenta um resumo do estado de conservação das áreas internas.

Tabela 19. Estado de conservação das áreas internas.

\begin{tabular}{lcccc}
\hline $\begin{array}{c}\text { Estado de Conservação } \\
\text { Áreas Internas }\end{array}$ & $\begin{array}{c}\text { Ótimo } \\
(\%)\end{array}$ & $\begin{array}{c}\text { Normal } \\
(\%)\end{array}$ & $\begin{array}{c}\text { Deficiente } \\
(\%)\end{array}$ & $\begin{array}{c}\text { Inexistente } \\
(\%)\end{array}$ \\
\hline Paredes e painéis de vedação $(\mathrm{n}=19)$ & 0 & 84 & 16 & 0 \\
\hline Estruturas $(\mathrm{n}=19)$ & 5 & 89 & 5 & 0 \\
\hline Pintura $(\mathrm{n}=19)$ & 0 & 58 & 42 & 0 \\
\hline Revestimento de piso $(\mathrm{n}=19)$ & 5 & 63 & 32 & 0 \\
\hline Revestimento de paredes $(\mathrm{n}=19)$ & 0 & 74 & 26 & 0 \\
\hline Forro (pintura e estrutura) $(\mathrm{n}=19)$ & 11 & 89 & 0 & 0 \\
\hline Esquadria de madeira $(\mathrm{n}=19)$ & 0 & 84 & 16 & 0 \\
\hline Esquadria de alumínio $(\mathrm{n}=19)$ & 5 & 42 & 53 & 0 \\
\hline Vidraçaria $(\mathrm{n}=19)$ & 5 & 63 & 32 & 0 \\
\hline
\end{tabular}


Tabela 19. Continuação

\begin{tabular}{lcccc}
\hline \multicolumn{1}{c}{$\begin{array}{c}\text { Estado de Conservação } \\
\text { Áreas Internas }\end{array}$} & $\begin{array}{c}\text { Ótimo } \\
(\%)\end{array}$ & $\begin{array}{c}\text { Normal } \\
(\%)\end{array}$ & $\begin{array}{c}\text { Deficiente } \\
(\%)\end{array}$ & $\begin{array}{c}\text { Inexistente } \\
(\%)\end{array}$ \\
\hline Instalações elétricas $(\mathrm{n}=19)$ & 5 & 58 & 37 & 0 \\
\hline $\begin{array}{l}\text { Instalações de telefonia, internet e TV } \\
(\mathrm{n}=19)\end{array}$ & 5 & 90 & 5 & 0 \\
\hline Instalações hidrossanitárias $(\mathrm{n}=19)$ & 0 & 79 & 21 & 0 \\
\hline Instalações de gás $(\mathrm{n}=19)$ & 0 & 37 & 63 & 0 \\
\hline
\end{tabular}

O estado de conservação Normal é o de maior frequência para todos os itens verificados, com exceção da Esquadria de Alumínio e da Instalação de Gás, nos quais a situação Deficiente é a mais frequente. Porém, há outras situaçôes críticas, como a da Pintura, do Revestimento do Piso, da Vidraçaria e das Instalaçóes Elétricas, em que a deficiência é alta.

\subsection{Vistoria de Áreas Externas}

$\mathrm{Na}$ vistoria das áreas externas, foram inspecionados o sistema de cobertura, a pavimentação (calçadas e acessos), as fachadas, as instalações de gás e diversos (caixa d'água, caixa de gordura).

A verificação da cobertura abrange itens relacionados à conservação de calhas e canaletas, impermeabilização, facilidade de acesso para manutenção e limpeza, fixação das telhas e acessórios, como calhas e rufos. A maioria dos itens que se adequavam ao caso atendeu todos os requisitos com frequência superior aos $84 \%$ (Tabela 27), e o estado de conservação foi avaliado como Ótimo (32\%), Normal (58\%) e Deficiente (11\%).

Tabela 27. Avaliação da cobertura.

\begin{tabular}{lcccc}
\hline \multicolumn{1}{c}{ Cobertura } & A & NA & NSA & NV \\
\hline $\begin{array}{l}\text { Calhas e canaletas limpas e funcionando, sem } \\
\text { empoçamento e grelhas hemisféricas }(\mathrm{n}=19)\end{array}$ & 0 & 0 & $\begin{array}{c}19 \\
(100 \%)\end{array}$ & 0 \\
\hline Impermeabilização - não há sinais de infiltração $(\mathrm{n}=19)$ & $\begin{array}{c}19 \\
(100 \%)\end{array}$ & 0 & 0 & 0 \\
\hline Há facilidade de acesso com segurança para manutenção e & $\begin{array}{c}19 \\
(100 \%)\end{array}$ & 0 & 0 & 0 \\
limpeza $(\mathrm{n}=19)$ & $\begin{array}{c}18 \\
(95 \%)\end{array}$ & $\begin{array}{c}1 \\
(5 \%)\end{array}$ & 0 & 0 \\
\hline Telhas devidamente fixadas $(\mathrm{n}=19)$ & $\begin{array}{c}19 \\
(100 \%)\end{array}$ & 0 & 0 & 0 \\
\hline Existência de acessórios: rufos, calhas e afins $(\mathrm{n}=19)$ & & & 0 \\
\hline
\end{tabular}


$\mathrm{Na}$ inspeção da pavimentaçáo, calçadas e acessos internos ao lote, foi verificada a presença de peças soltas, deformações, fissuras, desgastes, sinais de umidade e caimento do piso.

Os itens relacionados à pavimentação, às calçadas e aos acessos internos ao lote que atendem à frequência superior a $84 \%$ são: não há peças soltas (100\%), não há deformações (88\%), não há desgaste $(94 \%)$ e caimento da pavimentação (100\%). As verificaçôes que não atendem são: existência de fissuras $(58 \%)$ e de sinais de umidade (19\%), Tabela 28.

Tabela 28. Avaliação da pavimentação, calçada e acessos internos ao lote.

\begin{tabular}{lcccc}
\hline Pavimentação - Calçadas e Acesso Interno ao Lote & $\mathrm{A}$ & NA & NSA & NV \\
\hline Não há peças soltas $(\mathrm{n}=19)$ & $\begin{array}{c}19 \\
(100 \%)\end{array}$ & 0 & 0 & 0 \\
\hline Não há deformações $(\mathrm{n}=17)$ & $\begin{array}{c}15 \\
(88 \%)\end{array}$ & $\begin{array}{c}2 \\
(12 \%)\end{array}$ & 0 & 2 \\
\hline Não há fissuras $(\mathrm{n}=19)$ & $\begin{array}{c}8 \\
(42 \%)\end{array}$ & $\begin{array}{c}11 \\
(58 \%)\end{array}$ & 0 & 0 \\
\hline Não há desgaste $(\mathrm{n}=18)$ & $\begin{array}{c}17 \\
(94 \%)\end{array}$ & $\begin{array}{c}1 \\
(6 \%)\end{array}$ & 0 & 1 \\
\hline Não há sinais de umidade $(\mathrm{n}=16)$ & $\begin{array}{c}13 \\
(81 \%)\end{array}$ & $\begin{array}{c}3 \\
(19 \%)\end{array}$ & 0 & 3 \\
\hline Verificar caimento da pavimentação $(\mathrm{n}=18)$ & $\begin{array}{c}18 \\
(100 \%)\end{array}$ & 0 & 0 & 1 \\
\hline
\end{tabular}

As poucas deformações da pavimentação foram verificadas nos acessos internos ao lote (grau de risco regular). As fissuras foram observadas na pavimentação das calçadas (grau de risco mínimo). Os sinais de infiltração foram verificados na pavimentação dos acessos (grau de risco regular e crítico).

O estado geral da pavimentação foi avaliado como Normal (79\%) e Deficiente (21\%).

Os itens verificados relativos às Fachadas foram o estado de conservação da pintura, a impermeabilização, a facilidade de acesso para manutenção e limpeza, as fissuras e descolamentos dos revestimentos. Os que não foram atendidos, com a frequência inferior a $16 \%$ nas inspeçóes, referemse à: pintura - mau estado de conservação (42\%), fissuras perceptíveis nos revestimentos (84\%) e descolamento de revestimento (21\%), Tabela 29 e Figuras 10 e 11. 
Avaliação de Desempenho de Tecnologias Construtivas Inovadoras:

Conforto Ambiental, Durabilidade e Pós-Ocupação

Tabela 29. Avaliação das fachadas.

\begin{tabular}{lcccc}
\hline \multicolumn{1}{c}{ Fachadas } & A & NA & NSA & NV \\
\hline Pintura - estado de conservação $(\mathrm{n}=19)$ & $\begin{array}{c}11 \\
(58 \%)\end{array}$ & $\begin{array}{c}8 \\
(42 \%)\end{array}$ & 0 & 0 \\
\hline Impermeabilização (não há sinais de infiltração) $(\mathrm{n}=19)$ & $\begin{array}{c}16 \\
(84 \%)\end{array}$ & $\begin{array}{c}3 \\
(16 \%)\end{array}$ & 0 & 0 \\
\hline Há facilidade de acesso com segurança para a & $\begin{array}{c}17 \\
\text { manutenção e limpeza }(\mathrm{n}=19)\end{array}$ & $\begin{array}{c}2 \\
(89 \%)\end{array}$ & 0 & 0 \\
\hline Não há fissuras perceptíveis no revestimento $(\mathrm{n}=19)$ & $\begin{array}{c}3 \\
(16 \%)\end{array}$ & $\begin{array}{c}16 \\
(84 \%)\end{array}$ & 0 & 0 \\
\hline Não há descolamento de revestimento $(\mathrm{n}=19)$ & $\begin{array}{c}15 \\
(79 \%)\end{array}$ & $\begin{array}{c}4 \\
(21 \%)\end{array}$ & 0 & 0 \\
\hline
\end{tabular}

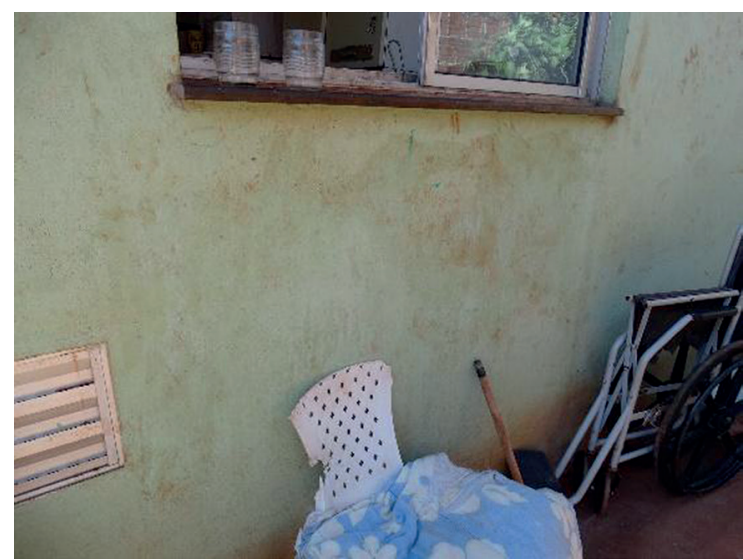

Figura 10. Pintura - estado de conservação, grau de risco mínimo.

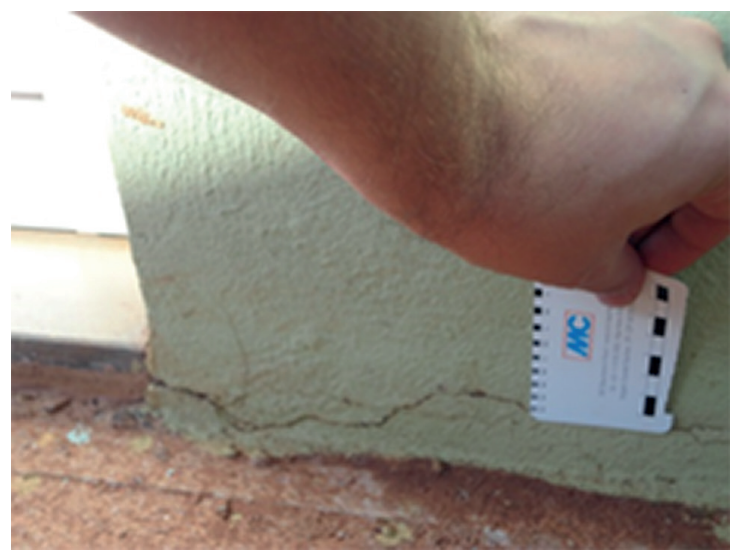

Figura 11. Fissuras perceptíveis no revestimento, grau de risco mínimo. 
O estado geral de conservação das fachadas foi avaliado como Normal (68\%) e Deficiente (32\%).

$\mathrm{Na}$ inspeção das Instalaçóes de gás, verificou-se o armazenamento, o abrigo dos medidores, as tubulaçôes e a facilidade de acesso para as mediçôes. Nesse caso, apenas um dos itens pôde ser avaliado (Tabela 30). Os demais itens se referem às instalaçôes de gás central ou de gás de rua, com central de medição instalada em área comum, portanto, não se aplicam para este caso.

Tabela 30. Avaliação de instalações de gás.

\begin{tabular}{lcccc}
\hline \multicolumn{1}{c}{ Instalações de Gás } & A & NA & NSA & NV \\
\hline $\begin{array}{l}\text { Armazenamento de gás está fora das edificações, } \\
\text { em ambiente exclusivo e com ventilação }(\mathrm{n}=19)\end{array}$ & $\begin{array}{c}2 \\
(11 \%)\end{array}$ & $\begin{array}{c}17 \\
(89 \%)\end{array}$ & 0 & 0 \\
\hline $\begin{array}{l}\text { Os abrigos dos medidores e dispositivos para } \\
\text { a medição são permanentemente ventilados e } \\
\text { iluminados ( } \mathrm{n}=19)\end{array}$ & 0 & 0 & $\begin{array}{c}19 \\
(100 \%)\end{array}$ & 0 \\
\hline $\begin{array}{l}\text { A tubulação de gás aparente está pintada na cor } \\
\text { amarela ( } \mathrm{n}=19)\end{array}$ & 0 & 0 & $\begin{array}{c}19 \\
(100 \%)\end{array}$ & 0 \\
\hline $\begin{array}{l}\text { As tubulações que afloram do piso ou parede no } \\
\text { local de medição do gás têm proteção anticorrosiva } \\
\text { até 50 mm além do ponto de afloramento ( } \mathrm{n}=19)\end{array}$ & 0 & 0 & $\begin{array}{c}19 \\
(100 \%)\end{array}$ & 0 \\
\hline $\begin{array}{l}\text { O local de medição do gás está em condições de } \\
\text { fácil acesso ( } \mathrm{n}=19)\end{array}$ & 0 & 0 & $\begin{array}{c}19 \\
(100 \%)\end{array}$ & 0 \\
\hline
\end{tabular}

O estado geral de conservação das instalações de gás foi avaliado como Normal (22\%) e Deficiente (78\%), principalmente devido ao armazenamento indevido do botijão.

$\mathrm{Na}$ inspeção das Instalaçóes Diversas, foi verificada a facilidade de acesso à caixa d'água, presença de vazamentos, impermeabilização, contenção da caixa d'água, caixa de gordura, para-raios e aterramentos. Outras instalaçôes foram vistoriadas e os resultados são apresentados na Tabela 31, abaixo. Observa-se que algumas instalaçôes não foram verificadas, principalmente devido a alguma dificuldade de acesso para avaliação. $\mathrm{O}$ sistema de para-raios era inexistente neste caso. 
Tabela 31 . Avaliação de outras instalações (diversas).

\begin{tabular}{|c|c|c|c|c|}
\hline $\begin{array}{c}\text { Diversos - Caixa D’água, Caixa de Gordura, } \\
\text { Para-Raios, Aterramento }\end{array}$ & A & NA & NSA & NV \\
\hline $\begin{array}{l}\text { Caixa d'água: facilidade de acesso com segurança } \\
\text { para a manutenção e inspeção }(n=19)\end{array}$ & $\begin{array}{c}19 \\
(100 \%)\end{array}$ & 0 & 0 & 0 \\
\hline Caixa d'água sem vazamentos ( $\mathrm{n}=18$ ) & $\begin{array}{c}16 \\
(89 \%)\end{array}$ & $\begin{array}{c}2 \\
(11 \%)\end{array}$ & 0 & 1 \\
\hline $\begin{array}{l}\text { Caixa d'água: verificar existência de contenção para } \\
\text { prevenir rompimento da caixa d'água }(n=19)\end{array}$ & 0 & 0 & 0 & 19 \\
\hline Caixa d'água: previsão de impermeabilização $(n=19)$ & 0 & 0 & 0 & 19 \\
\hline $\begin{array}{l}\text { Caixa de gordura: facilidade de acesso com } \\
\text { segurança para manutenção e inspeção }(n=18)\end{array}$ & $\begin{array}{c}16 \\
(89 \%)\end{array}$ & $\begin{array}{c}2 \\
(11 \%) \\
\end{array}$ & 0 & 1 \\
\hline Caixa de gordura sem vazamentos $(n=17)$ & $\begin{array}{c}16 \\
(94 \%)\end{array}$ & $\begin{array}{c}1 \\
(6 \%)\end{array}$ & 0 & 2 \\
\hline Para-raios e aterramentos $(n=19)$ & 0 & 0 & $\begin{array}{c}19 \\
(100 \%)\end{array}$ & 0 \\
\hline
\end{tabular}

O estado geral de conservação dessas instalaçōes, nos itens aplicáveis, foi considerado Normal para grande parte das situaçóes.

A Avaliaçáo geral das áreas externas (Tabela 32) apresenta um resumo dos itens atendidos e não atendidos, no qual a frequência de não atendimento superior a $16 \%$ pode ser visto nos seguintes itens: Pavimentação, Fachadas e Instalaçôes de Gás.

Tabela 32. Quadro geral da avaliação de áreas externas.

\begin{tabular}{|c|c|c|c|c|c|c|c|}
\hline Avaliação Geral & A & NA & NSA & A & NA & NSA & NV \\
\hline Cobertura & 75 & 1 & 19 & $79 \%$ & $1 \%$ & $20 \%$ & 0 \\
\hline $\begin{array}{l}\text { Pavimentação - calçadas e } \\
\text { acesso interno ao lote }\end{array}$ & 90 & 17 & 0 & $84 \%$ & $16 \%$ & $0 \%$ & 7 \\
\hline Fachadas & 62 & 33 & 0 & $65 \%$ & $35 \%$ & $0,0 \%$ & 0 \\
\hline Instalações de gás & 2 & 17 & 76 & $2 \%$ & $18 \%$ & $80 \%$ & 0 \\
\hline $\begin{array}{l}\text { Diversos - Caixa d'água, } \\
\text { caixa de gordura, para-raios, } \\
\text { aterramento }\end{array}$ & 67 & 5 & 19 & $74 \%$ & $6 \%$ & $21 \%$ & 42 \\
\hline Total & 296 & 73 & 114 & $61 \%$ & $15 \%$ & $24 \%$ & \\
\hline
\end{tabular}

O resumo do estado de conservaçáo das áreas externas pode ser visto na Tabela 33 a, seguir. A situação mais crítica está nas instalaçóes de gás, apontada como Deficiente em 78\% das situaçóes. 
Tabela 33. Estado de conservação das áreas externas.

\begin{tabular}{lcccc}
\hline \multicolumn{1}{c}{$\begin{array}{c}\text { Estado geral de Conservação } \\
\text { Áreas externas }\end{array}$} & Ótimo & Normal & Deficiente & Inexistente \\
& $(\%)$ & $(\%)$ & $(\%)$ & $(\%)$ \\
\hline Cobertura $(\mathrm{n}=19)$ & 32 & 58 & 11 & 0 \\
\hline $\begin{array}{l}\text { Pavimentação - calçadas e acessos } \\
\text { internos ao lote }(\mathrm{n}=19)\end{array}$ & 0 & 79 & 21 & 0 \\
\hline Fachadas $(\mathrm{n}=19)$ & 0 & 68 & 32 & 0 \\
\hline Instalações de gás $(\mathrm{n}=19)$ & 0 & 22 & 78 & 0 \\
\hline $\begin{array}{l}\text { Diversos - caixa d'água, caixa de gordura, } \\
\text { para-raios e aterramentos }(\mathrm{n}=19)\end{array}$ & 0 & 22 & 11 & 0 \\
\hline
\end{tabular}

\section{Considerações Finais}

A aplicação dos instrumentos para avaliação de desempenho do sistema construtivo e da manutenção e manutenibilidade da edificação em estudo subsidiou dois tipos de reflexão, ora relacionadas ao sistema construtivo avaliado, ora ao instrumento em teste.

Em geral, os resultados diretamente relacionados ao sistema construtivo avaliado foram positivos, sem que problemas com impacto negativo expressivo à população tenham sido identificados. Apesar disso, foram identificadas algumas falhas, sistemáticas ou não, que impactam a qualidade da edificação, comprometendo indiretamente o desempenho do sistema em sua função específica. Isso ocorreu sistematicamente, por exemplo, em razão de problemas nos revestimentos dos banheiros e nas esquadrias de alumínio. Além disso, algumas falhas pontuais, como vazamentos em tubulaçóes no interior dos painéis de algumas unidades, apontam problemas na produção, transporte ou instalação desses elementos. Tal problema pode tanto ter origem em alguma deficiência em procedimentos de execução da obra, como ser resultado do uso de materiais inadequados em sua produção. Esse fenômeno alerta para os riscos de se considerar isoladamente a qualidade de um determinado sistema, sem verificar seu desempenho no conjunto, em condiçôes reais de aplicação, uso e manutenção.

A incidência de deficiências no sistema construtivo em decorrência da interação inadequada deste com materiais e componentes de baixa qualidade, evidencia também a necessidade de se dar mais atenção à especificação realizada em projeto. Pode se destacar, nesse caso, a importância de fortalecer 
a comunicação entre os fornecedores do sistema e seus componentes e a equipe desenvolvedora do empreendimento para garantir que as condiçóes de execução sejam adequadas. Outra falha de comunicação observada ocorreu com os moradores, que, por exemplo, resultou na utilizaçáo inadequada das instalaçóes de gás, podendo gerar risco grave de incêndio, explosão ou intoxicação em muitas residências por utilizarem o botijão de gás internamente, não respeitando a solução de projeto da unidade. Ambos os problemas observados estão intimamente relacionados a decisóes do projeto das unidades, que extrapolam o escopo de intervenção destes instrumentos, mas fomentam uma reflexão sobre os fatores que impactam a qualidade e segurança das habitações construídas.

É importante destacar as diferenças de abordagem nos dois instrumentos cuja aplicação foi discutida até aqui e como elas se complementam na avaliação das unidades habitacionais. Os itens da Ficha de Verificação da Obra foram estruturados a partir dos requisitos e dos parâmetros estabelecidos na Norma Brasileira de Desempenho em Edificaçóes Habitacionais - NBR 15575 (ABNT, 2013), já as Fichas para Avaliação da Manutenção tiveram em normas brasileiras e documentaçóes técnicas relativas à manutenção de sistemas e subsistemas construtivos e de instalaçôes prediais (IBAPE, 2009) a base para elaboração de seus itens de verificação. Ambas buscaram estabelecer uma estrutura geral de aplicação, de forma a uniformizar os dados levantados em várias tipologias de edificaçóes e diferentes sistemas construtivos. Contudo, durante a aplicação dos instrumentos, ficou evidente a necessidade de adequá-las às especificidades de avaliação de casos.

Além disso, constatou-se uma excessiva generalidade nas fichas de verificação das áreas externas relacionadas às instalaçóes elétricas, instalaçóes de gás, esquadrias e diversos, gerando muitos resultados em que os critérios "não se aplicam" ao projeto do empreendimento. Como a elaboração das fichas baseou-se, principalmente, em empreendimentos habitacionais multifamiliares e de múltiplos pavimentos, parte de suas questóes não se aplicavam a unidades habitacionais unifamiliares térreas acomodadas em lotes individuais, como ocorre no caso de estudo. Tal ambiguidade pode gerar dúvidas nos aplicadores e demandar maior tempo para aplicaçáo. 
Assim, em pesquisas futuras, torna-se interessante considerar possibilidades de desmembrar e aprimorar as fichas para as principais situaçóes encontradas em programas habitacionais atualmente, notadamente:

- Unidades habitacionais unifamiliares em lotes isolados;

- Unidades habitacionais unifamiliares em condomínios horizontais;

- Unidades habitacionais agrupadas verticalmente em edifícios multifamiliares de até 5 pavimentos;

- Unidades habitacionais agrupadas verticalmente em edifícios multifamiliares acima de 5 pavimentos.

Este capítulo apresentou os resultados da aplicação em campo de dois instrumentos utilizados para coleta de dados a fim de realizar a avaliação de desempenho e manutenção de unidades habitacionais edificadas com sistema construtivo inovador em um empreendimento específico, assim como para realizar uma avaliação da efetividade desses instrumentos. Tais instrumentos fazem parte de um método proposto, cujo conteúdo é apresentado nos Capítulos 9 a 10 deste livro e cujos resultados são discutidos de maneira integrada no Capítulo 11.

\section{Referências}

ASSOCIAÇÃO BRASILEIRA DE NORMAS TÉCNICAS - ABNT. NBR 10152: Níveis de ruído para conforto acústico - Procedimento. Rio de Janeiro, 1992.

ASSOCIAÇÃO BRASILEIRA DE NORMAS TÉCNICAS - ABNT. NBR 15575: Edificaçóes Habitacionais - Desempenho (Partes 1 à 5). Rio de Janeiro, 2013.

INSTITUTO BRASILEIRO DE AVALIAÇŌES E PERÍCIAS DE ENGENHARIA IBAPE. Norma de Inspeçáo predial do IBAPE. São Paulo, 2009.

FABRICIO, M.M.; ONO, R. (Orgs.). Avaliaçáo de Desempenho de Tecnologias Construtivas Inovadoras: Manutenção e Percepção do Usuário. Porto Alegre: ANTAC/ Caboverde, 2015. v. 1, 159 p. DOI: http://dx.doi.org/10.4322/978-85-89478-42-7 
